\title{
CONSTRUCTING THE ASIA-PACIFIC REGIONAL COOPERATION AND INTEGRATION INDEX: A PANEL APPROACH
}

\author{
Cyn-Young Park and Racquel Claveria
}

NO. 544

May 2018
ADB ECONOMICS WORKING PAPER SERIES 
ADB Economics Working Paper Series

\section{Constructing the Asia-Pacific Regional Cooperation and Integration Index: A Panel Approach}

Cyn-Young Park and Racquel Claveria

No. 544 | May 2018
Cyn-Young Park (cypark@adb.org) is a Director and Racquel Claveria (rclaveria.consultant@adb.org) is a Consultant of the Regional Cooperation and Integration Division in the Economic Research and Regional Cooperation Department of the Asian Development Bank.

The authors thank Mara Claire Tayag and the Asia Regional Integration Center staff (Clemence Fatima Cruz, Suzette Dagli, Pilar Dayag, Concepcion Latoja, Paul Mariano, and Dorothea Ramizo) for their devoted and timeless efforts in collecting and compiling data. 
(C) 2018 Asian Development Bank

6 ADB Avenue, Mandaluyong City, 1550 Metro Manila, Philippines

Tel +632632 4444; Fax +6326362444

www.adb.org

Some rights reserved. Published in 2018.

ISSN 2313-6537 (print), 2313-6545 (electronic)

Publication Stock No. WPS189334-2

DOI: http://dx.doi.org/10.22617/WPS189334-2

The views expressed in this publication are those of the authors and do not necessarily reflect the views and policies of the Asian Development Bank (ADB) or its Board of Governors or the governments they represent.

ADB does not guarantee the accuracy of the data included in this publication and accepts no responsibility for any consequence of their use. The mention of specific companies or products of manufacturers does not imply that they are endorsed or recommended by ADB in preference to others of a similar nature that are not mentioned.

By making any designation of or reference to a particular territory or geographic area, or by using the term "country" in this document, $A D B$ does not intend to make any judgments as to the legal or other status of any territory or area.

This work is available under the Creative Commons Attribution 3.0 IGO license (CC BY 3.0 IGO)

https://creativecommons.org/licenses/by/3.0/igo/. By using the content of this publication, you agree to be bound by the terms of this license. For attribution, translations, adaptations, and permissions, please read the provisions and terms of use at https://www.adb.org/terms-use\#openaccess.

This CC license does not apply to non-ADB copyright materials in this publication. If the material is attributed to another source, please contact the copyright owner or publisher of that source for permission to reproduce it. $\mathrm{ADB}$ cannot be held liable for any claims that arise as a result of your use of the material.

Please contact pubsmarketing@adb.org if you have questions or comments with respect to content, or if you wish to obtain copyright permission for your intended use that does not fall within these terms, or for permission to use the ADB logo.

Notes:

In this publication, “\$” refers to United States dollars.

Corrigenda to ADB publications may be found at http://www.adb.org/publications/corrigenda. 


\section{CONTENTS}

TABLES AND FIGURES

iv

ABSTRACT

I. INTRODUCTION

1

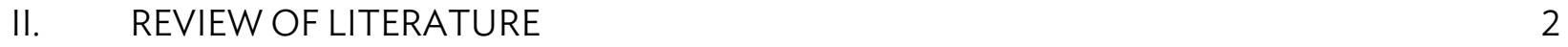

III. METHODOLOGY

A. Imputation of Missing Data 6

B. Normalization $\quad 7$

C. Weighting and Aggregation 8

IV. $\quad$ EMPIRICALRESULTS $\quad 9$

A. Panel Principal Component Analysis-Derived Weights 9

B. Overall and Dimensional Subindexes over Time 9

C. Performance of Asia Subregions 13

D. Leaders in Regional Integration 14

V. CONSTRUCTION OF INTRASUBREGIONAL INTEGRATION INDEX

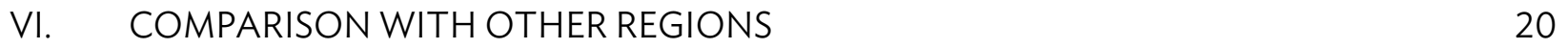

$\begin{array}{ll}\text { VII. ROBUSTNESS CHECKS } & 28\end{array}$

VIII. CONCLUSION

$\begin{array}{ll}\text { APPENDIX } & 37\end{array}$

$\begin{array}{ll}\text { REFERENCES } & 39\end{array}$ 


\section{TABLES AND FIGURES}

\section{TABLES}

1 Selected Studies Employing Multiperiod Principal Component Analysis in

Constructing Composite Indexes

2 General Data Availability and Imputation of Missing Values of Asia-Pacific

Regional Cooperation and Integration Index Indicators

3 Panel Principal Component Analysis and Weights for Aggregation for Asia

10

4 Asia-Pacific Regional Cooperation and Integration Index Dimensions and

Subdimensions, Panel Principal Component Analysis-Derived Weights

$5 \quad$ Panel Principal Component Analysis-Derived Weights-Asia Intraregional versus Intrasubregional Integration Indexes

6 Intrasubregional Integration Index, 2006-2016-Country Coverage 16

$7 \quad$ Economy Rankings-Regional Integration Indexes 25

8 Principal Component Analysis-Derived Weights 29

\section{FIGURES}

$1 \quad$ Overall Asia-Pacific Regional Cooperation and Integration Index 12

and Dimensional Subindexes-Asia

2 Dimensional Contribution to Asia-Pacific Regional Cooperation 12

and Integration Index-Asia

3 Overall Asia-Pacific Regional Cooperation and Integration Index-Asia Subregions 13

4 Dimensional Subindexes-Asia Subregions

5 Asia-Pacific Regional Cooperation and Integration Index, 2016 versus 2006

- Selected Asian Economies

6 Intrasubregional Integration Indexes 17

7 Dimensional Contribution to Intrasubregional Integration Indexes 18

8 Intrasubregional Dimensional Subindexes 19

9 Summary of Panel Principal Component Analysis-Derived Weights 20

10 Regional Integration Index-Asia versus Other Regions 21

11 Dimensional Contribution to Overall Regional Integration Index 22

12 Dimensional Subindexes-Asia versus Other Regions 24

13 Asia-Pacific Regional Cooperation and Integration Index, 2014, Asia Subregions 30

-Using Panel versus Cross-Section Principal Component Analysis-Derived Weights

14 Dimensional Subindexes, 2014, Asia Subregions-Using Panel versus

Cross-Section Principal Component Analysis-Derived Weights

15 Regional Integration Indexes, 2014, Asia versus Other Regions-Using

Panel versus Cross-Section Principal Component Analysis-Derived Weights

16 Dimensional Subindexes, 2014, Asia versus Other Regions-Using Panel

versus Cross-Section Principal Component Analysis-Derived Weights 


\begin{abstract}
In this paper, we propose a panel approach in the construction of the Asia-Pacific Regional Cooperation and Integration Index (ARCII) to strengthen the index's ability to track the progress of economic integration in the region over time. Panel-based procedures are employed in imputing missing values, normalizing raw data, and deriving dimensional and subdimensional weights via principal components analysis. Findings suggest the pace of integration in Asia was broadly steady over the 11-year sample period (2006-2016). However, modest gains have been made as a majority of economies in the sample have moved up in their levels of regional integration from 2006 to 2016. Of the six dimensions featured in the ARCII, trade and investment and movement of people are the main drivers of regional integration, while the money and finance dimension was the weakest link. Based on global normalization, Asia comes second to the European Union (EU) in progress on regional integration, but in recent years a few Asian economies have broken through to the top tier dominated by the EU economies.
\end{abstract}

Keywords: Asia, composite index, regional integration

JEL codes: $\mathrm{C} 38, \mathrm{C} 43, \mathrm{~F} 15$ 


\section{INTRODUCTION}

Regional integration is a dynamic process where a group or more than one neighboring countries cooperate to achieve common goals for mutual benefit. Regional cooperation and integration can take form in many different facets, such as promoting trade and investment, developing infrastructure, improving people's mobility, strengthening the provision of regional public goods, and providing the legal and institutional basis for international policy cooperation.

Depending on the goals and purposes, a multitude of regional integration initiatives have emerged around the world, and Asia is no exception (Huh and Park 2018). Indeed, the dynamic effects of regional cooperation and integration are often considered positive for the region's economic growth and development, particularly when driven by increased market size, exploitation of economies of scale, enhanced competition, increased investment, and technical transfers.

In 2017, the Asia Economic Integration Report of the Asian Development Bank unveiled a new composite index - the Asia-Pacific Regional Cooperation and Integration Index (ARCII) - to gauge the degree of regional cooperation and integration in Asia and the Pacific (ADB 2017). The ARCII aims to assess the extent to which each economy is integrated into the region, identify strengths and weaknesses of multiple regional integration drivers, and track progress in a comprehensive and systematic manner. Reflecting the multifaceted nature of regional integration, the ARCII combines 26 indicators categorized into six regional cooperation and integration dimensions: trade and investment, money and finance, regional value chains, infrastructure and connectivity, movement of people, and institutional and social integration.

Building on the methodology of Huh and Park (2017, 2018), the ARCII is compiled using weights obtained from a two-stage principal component analysis (PCA). ${ }^{1}$ In the first stage, the PCA apportions a weight to each indicator to construct subindexes for the six dimensions. In the second stage, the PCA is applied again to weight the subindexes and to compile the overall index. However, in Huh and Park $(2017,2018)$ the ARCII was based on data from a single year (2013), partly because data from other years were limited and failed to cover many small island countries in the Pacific. The singleyear ARCII was also a reflection of the difficulty of reaching a consensus on the best approach to create time-consistent weights for compiling indicators that may become suddenly available or missing over time. Nevertheless, the single-year ARCII lacked the capacity to capture the dynamic nature of regional integration.

In this paper, we extend the methodology of Huh and Park $(2017,2018)$ to enhance the ARCIl's ability to track progress in regional cooperation and integration in Asia and the Pacific over time, and to improve the reliability and ease of interpreting the index. In particular, panel normalization and panel PCA are employed in building an ARCII that can better monitor the time evolution of the index and identify different drivers of regional integration over time. A methodological refinementthe percentile transformation of normalized indicator values-also generates more robust and reliable estimates of ARCII. Finally, to the extent that availability of data allows, the construction of ARCII is brought to the subregional level by compiling indicators of activity between countries within each subregion (intrasubregional integration).

For a full discussion on the construction of ARCII, please see Huh and Park (2018) "Asia-Pacific Regional Integration Index: Construction, Interpretation and Comparison” by Hyeon-Seung Huh and Cyn-Young Park at https://doi.org/10.1016/j.asieco.2017.12.001. An earlier version appeared in the ADB Working Paper Series https://www.adb.org/publications/asia-pacific-regional-integration-index. The ARCII was referred to as Asia-Pacific Regional Integration Index (APRII) in these papers. 
The rest of the paper is structured as follows: Section II surveys some multiperiod PCA-based indicators. Section III details the extensions and refinements made to the methodology of Huh and Park (2018) in constructing the ARCII. Section IV presents the empirical results. Section $V$ shows the construction of subregional indexes for Asia. Section VI discusses comparison of ARCII with regional integration indexes constructed for other regions. Section VII lays out the robustness checks performed on the ARCII. Finally, section VIII concludes with some policy implications and directions for future research.

\section{REVIEW OF LITERATURE}

Discussion of time dimension and longitudinal datasets is relatively sparse in the composite index literature. Only a handful of studies detail the methodology for constructing multiperiod PCA-based composite indicators (some of these are summarized in Table 1). Despite PCA being the main statistical tool for building the composite indexes listed in Table 1, the methodological differences are noteworthy. Various techniques are employed in each step of building a composite index, from the imputation of missing data to the weighting and aggregation of the overall index. For instance, missing values are imputed through linear interpolation and substitution with latest/closest available data in the KOF Index of Globalization (Dreher 2006, Dreher et al. 2010, and Gygli, Haelg, and Sturm 2018) while in the survey-based Logistics Performance Index (LPI) absent data are replaced with country mean responses, adjusted by the respondent's average deviation from a country mean in answers to the survey questions (World Bank 2017).

Normalization methods likewise vary. The KOF Index of Globalization employs panel normalization (i.e., normalizing values based on all available countries and years on hand) via minmax scaling (Swiss Federal Institute of Technology Zurich 2017), LPI utilizes annual normalization (i.e., normalizing values for each year) through standardization (z-scores) while a composite index of economic integration in Asia and the Pacific developed by Bo and Woo (2008) used methodologies involving distance to reference/base year and the conversion of raw indicators to percent share to total.

With regard to weighting and aggregation of the composite indexes, Dreher (2006), Dreher et al. (2010), Bo and Woo (2008) applied panel PCA-generated weights for the KOF Index of Globalization and a composite index of economic integration in Asia and the Pacific, respectively. Nonetheless, an updated version of the KOF Index of Globalization utilized 10-year rolling panel PCAderived weights for compiling the index, with the intent of adapting to the changing relevance of certain variables in capturing globalization over time (Gygli, Haelg, and Sturm 2018). Meanwhile, PCAgenerated weights for specific years are utilized for each biennial edition of the LPI, as it is assumed that the steady year-to-year weights ensure a high degree of comparability across various LPI editions (World Bank 2017). 


\section{Table 1: Selected Studies Employing Multiperiod Principal Component Analysis in Constructing Composite Indexes}

\begin{tabular}{|c|c|c|c|c|c|c|}
\hline & Coverage & $\begin{array}{c}\text { Structure of } \\
\text { Composite } \\
\text { Index }\end{array}$ & $\begin{array}{l}\text { Imputation of } \\
\text { Missing Data }\end{array}$ & $\begin{array}{c}\text { Normalization } \\
\text { Method }\end{array}$ & $\begin{array}{c}\text { Multivariate } \\
\text { Analysis }\end{array}$ & $\begin{array}{l}\text { Weighting and } \\
\text { Aggregation }\end{array}$ \\
\hline $\begin{array}{l}\text { KOF Index of } \\
\text { Globalization } \\
2017 \text { version } \\
\text { (based on Dreher } \\
\text { 2006, Dreher et } \\
\text { al. 2010) }\end{array}$ & $\begin{array}{l}207 \text { countries } \\
1970-2014\end{array}$ & $\begin{array}{l}23 \text { indicators } \\
5 \text { subdimensions } \\
3 \text { dimensions }\end{array}$ & $\begin{array}{l}\text { Linear } \\
\text { interpolation; } \\
\text { Missing values at } \\
\text { the border are } \\
\text { replaced with } \\
\text { latest data }\end{array}$ & $\begin{array}{l}\text { Panel min-max } \\
\text { scaling, } \\
\text { normalized } \\
\text { values are then } \\
\text { adjusted } \\
\text { according to } \\
\text { percentile } \\
\text { distribution of } \\
\text { original values }\end{array}$ & $\begin{array}{l}\text { Multistage } \\
\text { principal } \\
\text { component } \\
\text { analysis (PCA) }\end{array}$ & $\begin{array}{l}\text { Additive using } \\
\text { panel PCA- } \\
\text { generated } \\
\text { weights }\end{array}$ \\
\hline $\begin{array}{l}\text { KOF Index of } \\
\text { Globalization } \\
2018 \text { version } \\
\text { (based on Gygli, } \\
\text { Haelg, and Sturm } \\
\text { (2018) }\end{array}$ & $\begin{array}{l}209 \text { countries } \\
1970-2015\end{array}$ & $\begin{array}{l}42 \text { indicators } \\
5 \text { subdimensions } \\
3 \text { dimensions } \\
1 \text { de facto } \\
\text { globalization } \\
\text { Index } \\
1 \text { de jure } \\
\text { globalization } \\
\text { index }\end{array}$ & $\begin{array}{l}\text { Linear } \\
\text { interpolation; } \\
\text { Missing values at } \\
\text { beginning/end of } \\
\text { series are } \\
\text { substituted by } \\
\text { the closest } \\
\text { observation } \\
\text { available }\end{array}$ & $\begin{array}{l}\text { Panel min-max } \\
\text { scaling, } \\
\text { normalized } \\
\text { values are then } \\
\text { adjusted } \\
\text { according to } \\
\text { percentile } \\
\text { distribution of } \\
\text { original values }\end{array}$ & Multistage PCA & $\begin{array}{l}\text { Additive using } \\
\text { 10-year rolling } \\
\text { panel PCA- } \\
\text { generated } \\
\text { weights }\end{array}$ \\
\hline $\begin{array}{l}\text { Composite Index } \\
\text { of Economic } \\
\text { Integration in } \\
\text { the Asia and } \\
\text { Pacific region } \\
\text { (Bo and Woo } \\
2008 \text { ) }\end{array}$ & $\begin{array}{l}17 \text { countries in } \\
\text { the Asia Pacific } \\
\text { Economic } \\
\text { Cooperation } \\
\text { (APEC) region } \\
\text { 1990-2005 }\end{array}$ & $\begin{array}{l}8 \text { indicators } \\
4 \text { dimensions }\end{array}$ & $\begin{array}{l}\text { Standard } \\
\text { interpolation and } \\
\text { extrapolation } \\
\text { techniques (not } \\
\text { specified) }\end{array}$ & $\begin{array}{l}\text { Distance to } \\
\text { reference/base } \\
\text { year (1990) } \\
\text { Percent share to } \\
\text { the Asia and } \\
\text { Pacific region }\end{array}$ & Two-stage PCA & $\begin{array}{l}\text { Additive using } \\
\text { panel PCA- } \\
\text { generated } \\
\text { weights }\end{array}$ \\
\hline $\begin{array}{l}\text { Logistics } \\
\text { Performance } \\
\text { Index (LPI) } \\
\text { (World Bank } \\
\text { 2017) }\end{array}$ & $\begin{array}{l}160 \text { countries } \\
2007,2010, \\
2012,2014,2016\end{array}$ & $\begin{array}{l}6 \text { indicators } \\
6 \text { dimensions }\end{array}$ & $\begin{array}{l}\text { Missing values } \\
\text { replaced with } \\
\text { country mean } \\
\text { response for each } \\
\text { question, } \\
\text { adjusted by } \\
\text { respondent's } \\
\text { average deviation } \\
\text { from country } \\
\text { mean in answered } \\
\text { questions }\end{array}$ & $\begin{array}{l}\text { Standardization } \\
\text { (z-scores) }\end{array}$ & PCA & $\begin{array}{l}\text { Additive using } \\
\text { year-specific } \\
\text { PCA-generated } \\
\text { weights }\end{array}$ \\
\hline $\begin{array}{l}\text { Asia-Pacific } \\
\text { Regional } \\
\text { Cooperation and } \\
\text { Integration Index } \\
\text { (ARCII) } \\
\text { (Park and } \\
\text { Claveria 2018) }\end{array}$ & $\begin{array}{l}158 \text { countries } \\
2006-2016\end{array}$ & $\begin{array}{l}26 \text { indicators } \\
6 \text { dimensions }\end{array}$ & $\begin{array}{l}\text { Interpolation } \\
\text { using linear } \\
\text { growth; } \\
\text { Averaging; } \\
\text { Missing values at } \\
\text { beginning/end of } \\
\text { series are } \\
\text { substituted by } \\
\text { the closest } \\
\text { observation } \\
\text { available }\end{array}$ & $\begin{array}{l}\text { Panel min-max } \\
\text { scaling, } \\
\text { normalized } \\
\text { values are then } \\
\text { adjusted } \\
\text { according to } \\
\text { percentile } \\
\text { distribution of } \\
\text { original values }\end{array}$ & Two-stage PCA & $\begin{array}{l}\text { Additive using } \\
\text { panel PCA- } \\
\text { generated } \\
\text { weights }\end{array}$ \\
\hline
\end{tabular}


Table 2: General Data Availability and Imputation of Missing Values of Asia-Pacific Regional Cooperation and Integration Index Indicators

\begin{tabular}{|c|c|c|c|c|c|c|c|c|c|c|c|c|c|}
\hline Dimension & & Indicator & 2006 & 2007 & 2008 & 2009 & 2010 & 2011 & 2012 & 2013 & 2014 & 2015 & 2016 \\
\hline \multirow{5}{*}{$\begin{array}{l}\text { I. } \\
\text { Trade and } \\
\text { Investment } \\
\text { Integration }\end{array}$} & $1-\mathrm{a}$ & $\begin{array}{l}\text { Proportion of intraregional goods exports } \\
\text { to total goods exports }\end{array}$ & & & & & & & & & & & \\
\hline & $1-b$ & \begin{tabular}{|l|} 
Proportion of intraregional goods \\
imports to total goods imports
\end{tabular} & & & & & & & & & & & \\
\hline & I-c & Intraregional trade intensity index & & & & & & & & & & & \\
\hline & I-d & $\begin{array}{l}\text { Proportion of intraregional foreign direct } \\
\text { investment (FDI) inflows to total FDI } \\
\text { inflows }\end{array}$ & & & & & & & & & & & \\
\hline & $I-e$ & $\begin{array}{l}\text { Proportion of intraregional FDI inflows } \\
\text { plus outflows to total FDI inflows plus } \\
\text { outflows }\end{array}$ & & & & & & & & & & & \\
\hline \multirow{4}{*}{$\begin{array}{l}\text { II. } \\
\text { Money and } \\
\text { Finance } \\
\text { Integration }\end{array}$} & II-a & $\begin{array}{l}\text { Proportion of intraregional cross-border } \\
\text { equity liabilities to total cross-border } \\
\text { equity liabilities }\end{array}$ & & & & & & & & & & & \\
\hline & $\mathrm{II}-\mathrm{b}$ & $\begin{array}{l}\text { Proportion of intraregional cross-border } \\
\text { bond liabilities to total cross-border } \\
\text { bond liabilities }\end{array}$ & & & & & & & & & & & \\
\hline & II-c & $\begin{array}{l}\text { Pair-wise dispersion of average regional } \\
\text { deposit rates relative to average global } \\
\text { deposit rates }\end{array}$ & & & & & & & & & & & \\
\hline & III-d & $\begin{array}{l}\text { Pair-wise correlation of average regional } \\
\text { equity returns minus average global } \\
\text { equity returns }\end{array}$ & & & & & & & & & & & \\
\hline \multirow[t]{2}{*}{$\begin{array}{l}\text { III. } \\
\text { Regional Value } \\
\text { Chain }\end{array}$} & III-a & $\begin{array}{l}\text { Ratio between the average trade } \\
\text { complementarity index over regional } \\
\text { trading partners and the average trade } \\
\text { complementarity index over all trading } \\
\text { partners }\end{array}$ & & & & & & & & & & & \\
\hline & III-b & $\begin{array}{l}\text { Ratio between the average trade } \\
\text { concentration index over regional trading } \\
\text { partners and the average trade } \\
\text { concentration index over all trading } \\
\text { partners }\end{array}$ & & & & & & & & & & & \\
\hline
\end{tabular}


Table 2 continued

\begin{tabular}{|c|c|c|c|c|c|c|c|c|c|c|c|c|c|}
\hline \multirow[t]{3}{*}{ Dimension } & \multicolumn{2}{|r|}{ Indicator } & \multirow[t]{2}{*}{2006} & \multirow[t]{2}{*}{2007} & \multirow[t]{2}{*}{2008} & \multirow[t]{2}{*}{2009} & \multirow[t]{2}{*}{2010} & \multirow[t]{2}{*}{2011} & \multirow[t]{2}{*}{2012} & \multirow[t]{2}{*}{2013} & \multirow[t]{2}{*}{2014} & \multirow[t]{2}{*}{2015} & \multirow[t]{2}{*}{2016} \\
\hline & III-C & $\begin{array}{l}\text { Proportion of intraregional intermediate } \\
\text { goods exports to total intraregional } \\
\text { goods exports }\end{array}$ & & & & & & & & & & & \\
\hline & III-d & $\begin{array}{l}\text { Proportion of intraregional intermediate } \\
\text { goods imports to total intraregional } \\
\text { goods imports }\end{array}$ & & & & & & & & & & & \\
\hline \multirow[t]{4}{*}{$\begin{array}{l}\text { IV. } \\
\text { Infrastructure } \\
\text { and } \\
\text { Connectivity }\end{array}$} & IV-a & $\begin{array}{l}\text { Ratio between the average trade cost } \\
\text { over regional trading partners and the } \\
\text { average trade cost over all trading } \\
\text { partners }\end{array}$ & & & & & & & & & & & \\
\hline & $I V-b$ & $\begin{array}{l}\text { Ratio between the average liner shipping } \\
\text { connectivity index over regional trading } \\
\text { partners and the average liner shipping } \\
\text { connectivity index over all trading } \\
\text { partners }\end{array}$ & & & & & & & & & & & \\
\hline & IV-c & Logistics performance index (overall) & & & & & & & & & & & \\
\hline & IV-d & Doing business index (overall) & & & & & & & & & & & \\
\hline \multirow{4}{*}{$\begin{array}{l}\text { V. } \\
\text { Movement of } \\
\text { People }\end{array}$} & $V-a$ & $\begin{array}{l}\text { Proportion of intraregional outbound } \\
\text { migration to total outbound migration }\end{array}$ & & & & & & & & & & & \\
\hline & $\mathrm{V}-\mathrm{b}$ & $\begin{array}{l}\text { Proportion of intraregional tourists to } \\
\text { total tourists (inbound plus outbound) }\end{array}$ & & & & & & & & & & & \\
\hline & $\mathrm{V}-\mathrm{c}$ & $\begin{array}{l}\text { Proportion of intraregional remittances } \\
\text { to total remittances }\end{array}$ & & & & & & & & & & & \\
\hline & V-d & $\begin{array}{l}\text { Proportion of other Asian countries that } \\
\text { do not require an entry visa }\end{array}$ & & & & & & & & & & & \\
\hline \multirow{5}{*}{$\begin{array}{l}\text { VI. } \\
\text { Institutional } \\
\text { and Social } \\
\text { Integration }\end{array}$} & $\mathrm{VI}-\mathrm{a}$ & $\begin{array}{l}\text { Proportion of other Asian countries that } \\
\text { have signed free trade agreements }\end{array}$ & & & & & & & & & & & \\
\hline & $\mathrm{VI}-\mathrm{b}$ & $\begin{array}{l}\text { Proportion of other Asian countries that } \\
\text { have an embassy }\end{array}$ & & & & & & & & & & & \\
\hline & $\mathrm{VI}-\mathrm{c}$ & $\begin{array}{l}\text { Proportion of other Asian countries that } \\
\text { have signed business investment treaties }\end{array}$ & & & & & & & & & & & \\
\hline & VI-d & $\begin{array}{l}\text { Proportion of other Asian countries that } \\
\text { have signed double taxation treaties }\end{array}$ & & & & & & & & & & & \\
\hline & VI-e & $\begin{array}{l}\text { Cultural proximity with other Asian } \\
\text { countries relative to that with all other } \\
\text { countries }\end{array}$ & & & & & & & & & & & \\
\hline
\end{tabular}

Legend: Data available Source: Authors' compilation.
Used earliest available data Used average of available data for even years before and after
Linearly interpolated 


\section{METHODOLOGY}

The aim of this paper is to show how the ARCII's ability to track progress of regional integration in Asia and the Pacific over time is strengthened by using a panel to build the index. Specifically, a panel approach helps compute the PCA weights for compiling the variables and subindexes. This method ensures comparability, which offers a host of advantages in interpreting composite indexes across different periods. First, it allows for analysis of the time evolution of regional integration for each economy. An increase (decrease) in the index through time indicates an improvement (decline) in regional integration. Moreover, absolute changes in the scores for a specific economy, group, or subgroup of economies add meaning to a numeric value to the estimated regional integration. When the PCA weights were computed for each period, the numeric value of an economy's estimated regional integration means nothing but its ranking vis-à-vis other economies. However, changes in comparable composite index scores across periods indicate the absolute evolution in regional integration (UNCTAD 2007). Comparability also helps identify the dimensions that are driving major changes in the composite index for each economy or region across different time periods.

The overall empirical strategy to achieve comparability is to utilize the available information from the whole sample of countries and years in each of the different steps taken in building the index, particularly in the data imputation, normalization, and weighting and aggregation stages.

\section{A. Imputation of Missing Data}

We follow Huh and Park $(2017,2018)$ for the composition of ARCII index and the country coverage used, but the dataset is extended to cover 2006-2016 instead of utilizing 2013 data only. As shown in Table 2, data is available for most of the indicators (17 out of 26) across most of the countries. The imputation methods of Huh and Park $(2017,2018)$ are applied to fill in the data gaps. In particular, indicator $\mathrm{V}-\mathrm{a}$ (the proportion of intraregional outbound migration to total outbound migration) is linearly interpolated using bilateral migration data that is published every 5 years. For indicator $\mathrm{V}-\mathrm{c}$ (the Logistics Performance Index), an average of available data in even years is used to impute missing data for the odd years in between.

For several indicators that lack data for specific countries, such as IV-a (regional and global average trade cost ratio), IV-c (LPI), and IV-c (the World Bank's Doing Business Index), regression imputation is likewise employed, as in Huh and Park $(2017,2018){ }^{2}$ However, in place of data for all countries from a single year only, data for the regression imputation cover the entire sample of countries and years. ${ }^{3}$ This is in line with the goal of ensuring comparability of ARCII over time by employing all the information available across the whole sample period.

Meanwhile, instead of linear extrapolation, missing observations at the beginning or end of a series are substituted by the closest observation available. In effect, the last nonmissing observation is carried backward (forward) when observations are missing at the beginning (end) of a series. This is similar to the technique adopted by Gygli, Haelg, and Sturm (2018) to update the methodology used to construct the KOF Index of Globalization.

Appendix 3 of Huh and Park (2018) shows the specification of the regression imputation models.

Regression results used for data imputation are summarized in the appendix table. Columns I and II compare the results of Huh and Park (2018) and this study which both show correctly signed and significant coefficients. 


\section{B. Normalization}

Caution needs to be exercised in choosing the normalization method (e.g., panel or annual normalization) as different methods yield different outcomes and offer their own advantages and disadvantages. Moreover, attention should be paid to outliers as they can lead to unreliable or biased results.

As mentioned in section II, panel normalization involves normalizing indicators based on all sample years and all economies at hand. It is suitable for comparing progress across different economies through the years. However, whenever new data points become available, all indicators need to be normalized again using the new panel. A new dataset could change the minimum and maximum values for some indicators, and hence the value of the transformed indicators and resulting composite index. To maintain comparability between existing and new data, the composite index needs to be recalculated using the updated dataset (OECD 2008).

As an alternative to panel normalization, indicators for each year can be normalized-i.e., through annual normalization, which is similar to the methodology used to compute the single-year index. Typically, weights derived for a base year are applied to other years. As a result, previously constructed indexes are not affected. However, each year may have a different base for normalization (e.g., minimum and maximum values), which raises comparability issues over time.

Panel normalization is said to induce a "nonseparability" between years in a sample: a change in the data from 1 year can induce a change in ranking from another year (Lockwood 2004). Meanwhile, in annual normalization, use of different scales, means, and distributions will alter any weights assigned to the different components and therefore change the relative composition of the index (Dreher et al. 2010).

In this paper, we opt to employ panel normalization to maintain time consistency of the index. Specifically, a time element was added to the min-max scaling utilized by Huh and Park $(2017,2018)$. Each individual indicator $x_{q c}^{t}$ of type $q$ for a country $c$ and time $t$, is transformed into:

$$
I_{t}=\frac{x_{q c}^{t}-\min _{t \in T} \min _{c}\left(x_{q}^{t}\right)}{\max _{t \in T} \max _{c}\left(x_{q}^{t}\right)-\min _{t \in T} \min _{c}\left(x_{q}^{t}\right)}
$$

where the minimum and maximum values for each indicator are calculated across countries and time. The values of $I_{t}$ range from 0 to 1, with higher values denoting greater integration. For indicators where higher values of the original variable imply lower integration, such as II-c (pairwise dispersion of deposit rates), III-b (average trade concentration ratio), and IV-a (average trade cost ratio), the transformation is given as:

$$
I_{t}=1-\frac{x_{q c}^{t}-\min _{t \in T} \min _{c}\left(x_{q}^{t}\right)}{\max _{t \in T} \max _{c}\left(x_{q}^{t}\right)-\min _{t \in T} \min _{c}\left(x_{q}^{t}\right)}
$$

Hence, the minimum and maximum for each indicator are calculated across countries and time to account for the evolution of the indicators and the resulting composite index. 
One of the drawbacks of min-max scaling is that extreme values can distort the distribution of normalized values. This can also understate/overstate the resulting composite index. To prevent outliers from exerting undue influence over the normalized indicators and the composite index, we transform the normalized data in accordance with the percentile distribution of the raw indicators, as in Dreher et al. (2010).

\section{Weighting and Aggregation}

Weighting and aggregation of data continue to be guided by the goal of improving comparability by utilizing all information at hand. The most important source of incomparability is said to be the systemic statistical properties of the index components that affect weighting (UNCTAD 2007). To avoid this issue, reference weights must be applied to all the years in the sample period. This makes the comparison of the composite index across the years possible.

PCA remains the main statistical tool to obtain the weights utilized for compiling the ARCII. In this paper, a panel PCA estimation is carried out to obtain time-consistent weights for aggregation. Following the notation of Huh and Park $(2017,2018)$, the data vector $X=\left(x_{1}, x_{2}, \ldots, x_{Q}\right)$ becomes a multidimensional data vector $X_{T x Q}=\left(x_{1}^{t}, x_{2}^{t}, \ldots, x_{Q}^{t}\right), t \in T$, where $T$ is the total number of periods and $Q$ is the number of indicator (dimensions). Let $\Sigma_{Q x Q}$ be the correlation matrix of $X_{T x Q}$. The principal component (PC), $Z_{i}^{t}, i=1,2, \ldots, Q, t \in T$, is defined as

$$
\begin{aligned}
& Z_{1}^{t}=a_{11} x_{1}^{t}+a_{12} x_{1}^{t}+\cdots+a_{1 Q} x_{1}^{t} \\
& Z_{2}^{t}=a_{21} x_{1}^{t}+a_{22} x_{1}^{t}+\cdots+a_{2 Q} x_{1}^{t} \\
& Z_{Q}^{t}=a_{Q 1} x_{1}^{t}+2_{Q 2} x_{1}^{t}+\cdots+a_{Q Q} x_{1}^{t}
\end{aligned}
$$

Or in matrix form, $Z=A^{\prime} X_{T x Q}$ where $A=\left(a_{1}, a_{2}, \ldots, a_{Q}\right)$. The coefficient matrix $A$ maximizes the variance of $Z=E\left(Z Z^{\prime}\right)=A^{\prime} \sum A$ subject to the following constraints:

$$
\begin{gathered}
a_{1}^{\prime} a_{1}=a_{2}^{\prime} a_{2}=\cdots=a_{Q}^{\prime} a_{Q}=1 \text { (unit vector length) and } \\
\operatorname{cov}\left(a_{i}^{\prime} x, a_{j}^{\prime} x\right)=0, i \neq j \text { (orthogonality condition) }
\end{gathered}
$$

The solution to the eigenvalue-eigenvector problem resulting from the above-constrained maximization problem is $\lambda_{i}$, which is equal to the variance of $Z$. Moreover, $\lambda_{1}>\lambda_{2}>\cdots>\lambda_{Q}$.

Using the loadings obtained from the panel PCA, we follow a weighting scheme laid out in Huh and Park (2017, 2018). As mentioned, the ARCII is compiled using weights obtained from a two-stage panel PCA. In the first stage, panel PCA is employed to apportion a weight to each indicator to construct subindexes for the six dimensions of regional integration. In the second stage, panel PCA is applied again to weight the subindexes to compile the overall index.

Panel PCA-derived weights are used as reference weights in computing the ARCII for each year of the sample period. Keeping the weights constant over time is useful in analyzing the evolution of the ARCII for each economy and regional/subregional grouping. It also allows comparison of the composite index across the years. 


\section{EMPIRICAL RESULTS}

\section{A. Panel Principal Component Analysis-Derived Weights}

Following the two-step panel PCA procedure and the criteria for retaining the number of principal components cited in Huh and Park $(2017,2018)$, the right bottom portion of Table 3 reports the weights apportioned to each of the six dimensions of the ARCII, while Table 4 shows the weights of indicators for each dimension. ${ }^{4}$ Taking into account all the available information from 48 Asian countries for 2006-2016, the highest weight (0.187) was allocated to Dimension I (trade and investment) while the lowest weight (0.116) was given to Dimension II (money and finance). This lends credence to recent findings that financial integration in Asia continues to lag behind trade integration and that Asia's financial markets remains more globally than regionally integrated (ADB 2017).

\section{B. Overall and Dimensional Subindexes over Time}

Figure 1 shows a broadly steady trend of overall regional integration in Asia over the years. This indicates that regional integration is usually a gradual process (Bo and Woo 2008). The ARCII reflects a modest pace of integration over the period of 2006-2016. The dimensional subindexes mirrored the stable movement of the overall index. Among the subindexes, Dimension I (trade and investment) and $\checkmark$ (movement of people) maintained relatively higher scores than the overall index throughout the sample period. Dimension III (regional value chain) and IV (infrastructure and connectivity) broadly tracked the overall index. Dimension II (money and finance) and VI (institutional and social integration) showed relatively lower integration. Dimension II also exhibited the highest volatility. This subindex increased sharply in 2008, coinciding with the height of the global financial crisis, and picked up again in 2011 before the crisis drew to a close, stabilizing thereafter. The pattern illustrates the phenomenon that financial market interconnectedness tends to increase during stress periods and to decline during recovery (Dungey et al. 2017).

Figure 2 presents the contribution of each dimensional index to the overall composite index. Trade and investment along with movement of people seem to be the main drivers of regional integration in Asia. Infrastructure and connectivity comes a close third in its contribution to the overall index. While the institutional and social integration dimension presented the consistently lowest scores among the six dimensions over the sample period, money and finance had the lowest weight and dimensional contribution in the estimated panel ARCII. Therefore, money and finance integration seems to be the weakest link in regional integration in Asia.

4 Huh and Park (2018) followed the standard practice of choosing principal components that (i) have associated eigenvalues exceeding 1 (Kaiser criterion), (ii) contribute individually to the explanation of total variance by at least $10 \%$, and (iii) contribute cumulatively to explain more than $60 \%$ of total variance. 
Table 3: Panel Principal Component Analysis and Weights for Aggregation for Asia

\begin{tabular}{|c|c|c|c|c|c|c|c|c|c|c|c|c|c|c|c|c|c|}
\hline \multirow{8}{*}{$\begin{array}{l}\text { Eigenvalue } \\
\text { Prop. } \\
\text { Cum prop }\end{array}$} & \multicolumn{17}{|c|}{ Number of Principal Components } \\
\hline & \multicolumn{5}{|c|}{ Dimension I } & \multicolumn{4}{|c|}{ Dimension II } & \multicolumn{4}{|c|}{ Dimension III } & \multicolumn{4}{|c|}{ Dimension IV } \\
\hline & 1 & 2 & 3 & 4 & 5 & 1 & 2 & 3 & 4 & 1 & 2 & 3 & 4 & 1 & 2 & 3 & 4 \\
\hline & 3.257 & 1.129 & 0.400 & 0.119 & 0.096 & 1.759 & 0.959 & 0.783 & 0.499 & 1.971 & 0.893 & 0.692 & 0.444 & 1.648 & 1.102 & 0.883 & 0.368 \\
\hline & 0.651 & 0.226 & 0.080 & 0.024 & 0.019 & 0.440 & 0.240 & 0.196 & 0.125 & 0.493 & 0.223 & 0.173 & 0.111 & 0.412 & 0.275 & 0.221 & 0.092 \\
\hline & 0.651 & 0.877 & 0.957 & 0.981 & 1.000 & 0.440 & 0.680 & 0.875 & 1.000 & 0.493 & 0.716 & 0.889 & 1.000 & 0.412 & 0.687 & 0.908 & 1.000 \\
\hline & \multicolumn{4}{|c|}{ Dimension V } & \multicolumn{5}{|c|}{ Dimension VI } & \multicolumn{8}{|c|}{ Overall } \\
\hline & 1 & 2 & 3 & 4 & 1 & 2 & 3 & 4 & 5 & & 1 & 2 & 3 & 4 & 5 & 6 & \\
\hline \multirow{3}{*}{$\begin{array}{l}\text { Eigenvalue } \\
\text { Prop } \\
\text { Cum prop }\end{array}$} & 1.508 & 1.186 & 0.782 & 0.524 & 2.782 & 1.012 & 0.772 & 0.309 & 0.125 & & 2.319 & 1.283 & 1.014 & 0.712 & 0.460 & 0.212 & \\
\hline & 0.377 & 0.297 & 0.196 & 0.131 & 0.556 & 0.202 & 0.154 & 0.062 & 0.025 & & 0.387 & 0.214 & 0.169 & 0.119 & 0.077 & 0.035 & \\
\hline & 0.377 & 0.674 & 0.869 & 1.000 & 0.556 & 0.759 & 0.913 & 0.975 & 1.000 & & 0.387 & 0.600 & 0.769 & 0.888 & 0.965 & 1.000 & \\
\hline \multirow{8}{*}{$\begin{array}{l}Z_{1} \\
Z_{2} \\
Z_{3}\end{array}$} & \multicolumn{17}{|c|}{ Squared loadings } \\
\hline & $\mathrm{I}-\mathrm{a}$ & $\mathrm{I}-\mathrm{b}$ & $\mathrm{I}-\mathrm{C}$ & $\mathrm{l}-\mathrm{d}$ & $\mathrm{I}-\mathrm{e}$ & $\mathrm{II}-\mathrm{a}$ & $11-b$ & $\mathrm{II}-\mathrm{c}$ & II-d & $\mathrm{III}-\mathrm{a}$ & $\mathrm{III-b}$ & $\mathrm{III}-\mathrm{C}$ & $\mathrm{III}-\mathrm{d}$ & IV-a & $\mathrm{IV}-\mathrm{b}$ & IV-c & IV-d \\
\hline & 0.190 & 0.236 & 0.249 & 0.174 & 0.151 & 0.347 & 0.317 & 0.234 & 0.101 & 0.288 & 0.281 & 0.180 & 0.251 & 0.021 & 0.102 & 0.455 & 0.422 \\
\hline & 0.154 & 0.051 & 0.133 & 0.302 & 0.360 & 0.120 & 0.195 & 0.257 & 0.428 & 0.077 & 0.028 & 0.811 & 0.084 & 0.518 & 0.378 & 0.044 & 0.060 \\
\hline & $\mathrm{V}-\mathrm{a}$ & $\mathrm{V}-\mathrm{b}$ & $\mathrm{V}-\mathrm{c}$ & $V-d$ & $\mathrm{VI}-\mathrm{a}$ & $\mathrm{VI}-\mathrm{b}$ & $\mathrm{VI}-\mathrm{C}$ & VI-d & VI-e & & 1 & II & III & IV & $\mathrm{V}$ & $\mathrm{VI}$ & \\
\hline & 0.356 & 0.351 & 0.264 & 0.028 & 0.155 & 0.275 & 0.271 & 0.290 & 0.010 & & 0.212 & 0.173 & 0.030 & 0.154 & 0.341 & 0.091 & \\
\hline & 0.013 & 0.011 & 0.089 & 0.887 & 0.223 & 0.001 & 0.013 & 0.010 & 0.754 & & 0.051 & 0.106 & 0.395 & 0.163 & 0.048 & 0.237 & \\
\hline & & & & & & & & & & & 0.302 & 0.001 & 0.141 & 0.227 & 0.008 & 0.322 & \\
\hline \multirow{5}{*}{$\begin{array}{l}\text { Indicator } \\
\text { Weight } \\
\text { Indicator } \\
\text { Weight }\end{array}$} & \multicolumn{17}{|c|}{ Weights for composite indexes } \\
\hline & $\mathrm{I}-\mathrm{a}$ & $\mathrm{I}-\mathrm{b}$ & $\mathrm{I}-\mathrm{c}$ & $\mathrm{I}-\mathrm{d}$ & $\mathrm{I}-\mathrm{e}$ & $\mathrm{II}-\mathrm{a}$ & $\mathrm{II}-\mathrm{b}$ & $\mathrm{II}-\mathrm{c}$ & II-d & $\mathrm{III}-\mathrm{a}$ & $\mathrm{III-b}$ & III-C & III-d & IV-a & IV-b & IV-c & IV-d \\
\hline & 0.180 & 0.188 & 0.219 & 0.208 & 0.206 & 0.237 & 0.258 & 0.245 & 0.260 & 0.243 & 0.226 & 0.316 & 0.215 & 0.225 & 0.216 & 0.286 & 0.273 \\
\hline & $\mathrm{V}-\mathrm{a}$ & $V-b$ & $V-c$ & $V-d$ & $\mathrm{VI}-\mathrm{a}$ & VI-b & $\mathrm{VI}-\mathrm{c}$ & VI-d & VI-e & & 1 & II & III & IV & $\mathrm{V}$ & $\mathrm{VI}$ & \\
\hline & 0.248 & 0.244 & 0.209 & 0.299 & 0.173 & 0.199 & 0.199 & 0.213 & 0.216 & & 0.187 & 0.116 & 0.156 & 0.172 & 0.186 & 0.182 & \\
\hline
\end{tabular}

Notes: "Prop" and "Cum prop" rows report the fractions and cumulated fractions of total variation in the data accounted for by each principal component. Values in boldface are the principal components chosen for aggregation based on the criteria cited in Huh and Park (2018).

Source: Authors' calculations. 


\section{Table 4: Asia-Pacific Regional Cooperation and Integration Index Dimensions and Subdimensions,}

Panel Principal Component Analysis-Derived Weights

\begin{tabular}{|c|c|c|c|}
\hline \multicolumn{2}{|c|}{ Dimensions and Subdimensions } & \multicolumn{2}{|c|}{ Weights } \\
\hline I. $\operatorname{Tr}$ & and investment integration & & 0.187 \\
\hline $\mathrm{I}-\mathrm{a}$ & Proportion of intraregional goods exports to total goods exports & 0.180 & \\
\hline $1-b$ & Proportion of intraregional goods imports to total goods imports & 0.188 & \\
\hline $\mathrm{I}-\mathrm{c}$ & Intraregional trade intensity index & 0.219 & \\
\hline $\mathrm{I}-\mathrm{d}$ & Proportion of intraregional foreign direct investment (FDI) inflows to total FDI inflows & 0.208 & \\
\hline I-e & Proportion of intraregional FDI inflows plus outflows to total FDI inflows plus outflows & 0.206 & \\
\hline \multicolumn{2}{|r|}{ II. Money and finance integration } & & 0.116 \\
\hline II-a & Proportion of intraregional cross-border equity liabilities to total cross-border equity liabilities & 0.237 & \\
\hline II-b & Proportion of intraregional cross-border bond liabilities to total cross-border bond liabilities & 0.258 & \\
\hline $\mathrm{II}-\mathrm{c}$ & Pair-wise dispersion of deposit rates averaged regionally relative to that averaged globally & 0.245 & \\
\hline II-d & Pair-wise correlation of equity returns averaged regionally minus that averaged globally & 0.260 & \\
\hline \multicolumn{2}{|r|}{ III. Regional value chain } & & 0.156 \\
\hline III-a & $\begin{array}{l}\text { Ratio between the averaged trade complementarity index over regional trading partners and the averaged trade complementarity index } \\
\text { over all trading partners }\end{array}$ & 0.243 & \\
\hline III-b & $\begin{array}{l}\text { Ratio between the averaged trade concentration index over regional trading partners and the averaged trade concentration index over all } \\
\text { trading partners }\end{array}$ & 0.226 & \\
\hline III-c & Proportion of intraregional intermediate goods exports to total intraregional goods exports & 0.316 & \\
\hline III-d & Proportion of intraregional intermediate goods imports to total intraregional goods imports & 0.215 & \\
\hline \multicolumn{2}{|r|}{ IV. Infrastructure and connectivity } & & 0.172 \\
\hline IV-a & $\begin{array}{l}\text { Ratio between the averaged trade cost over regional trading partners and the averaged trade cost over all trading partners } \\
\text { Ratio between the averaged liner shipping connectivity index over regional trading partners and the averaged liner shipping connectivity }\end{array}$ & 0.225 & \\
\hline IV-b & index over all trading partners & 0.216 & \\
\hline IV-c & Logistics performance index (overall) & 0.286 & \\
\hline IV-d & Doing business index (overall) & 0.273 & \\
\hline \multicolumn{2}{|r|}{ V. Free movement of people } & & 0.186 \\
\hline $\mathrm{V}-\mathrm{a}$ & Proportion of intraregional outbound migration to total outbound migration & 0.248 & \\
\hline V-b & Proportion of intraregional tourists to total tourists (inbound plus outbound) & 0.244 & \\
\hline V-c & Proportion of intraregional remittances to total remittances & 0.209 & \\
\hline$V-d$ & Proportion of other Asian countries that do not require an entry visa & 0.299 & \\
\hline \multicolumn{2}{|r|}{ VI. Institutional and social integration } & & 0.182 \\
\hline $\mathrm{VI}-\mathrm{a}$ & Proportion of other Asian countries that have signed free trade agreements & 0.173 & \\
\hline $\mathrm{VI}-\mathrm{b}$ & Proportion of other Asian countries that have an embassy & 0.199 & \\
\hline $\mathrm{VI}-\mathrm{c}$ & Proportion of other Asian countries that have signed business investment treaties & 0.199 & \\
\hline VI-d & Proportion of other Asian countries that have signed double taxation treaties & 0.213 & \\
\hline $\mathrm{VI}-\mathrm{e}$ & Cultural proximity with other Asian countries relative to that with all other countries & 0.216 & \\
\hline
\end{tabular}

Source: Authors' calculations. 
Figure 1: Overall Asia-Pacific Regional Cooperation and Integration Index and Dimensional Subindexes-Asia

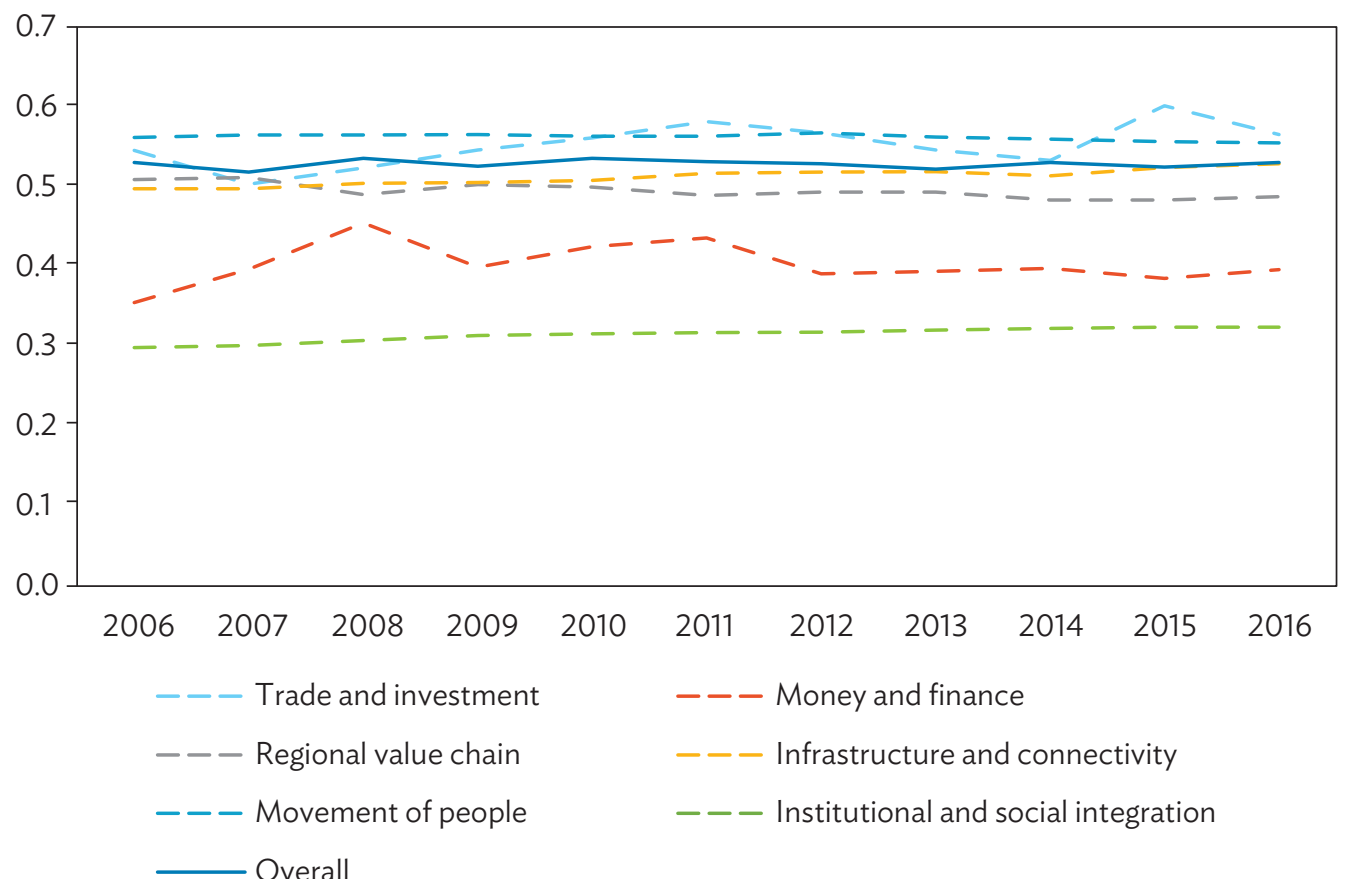

Source: Authors' calculations

Figure 2: Dimensional Contribution to Asia-Pacific Regional Cooperation and Integration Index-Asia

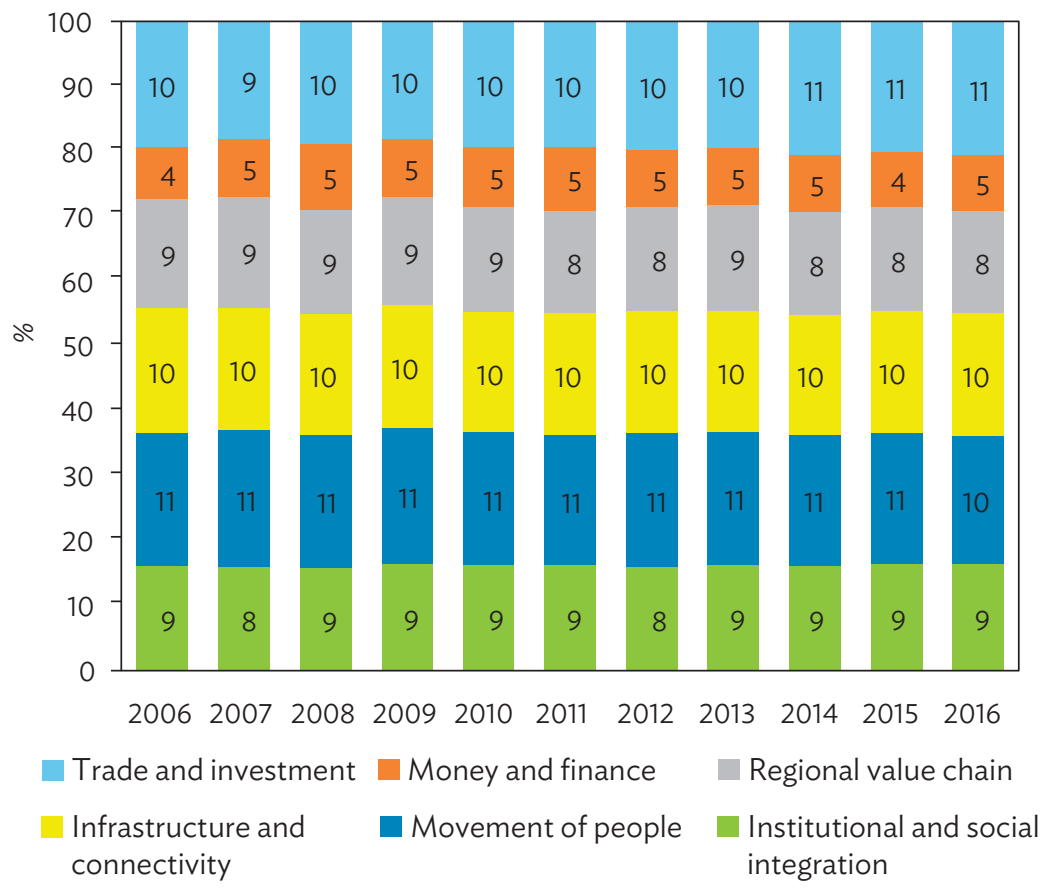

Source: Authors' calculations. 


\section{Performance of Asia Subregions}

Across the subregions, Southeast Asia exhibited the highest degree of integration for the sample period, except in 2016, with an average score of 0.590 (Figure 3). East Asia showed an overall upward trend of regional integration from its lowest of 0.547 in 2007. It recorded a score higher than Southeast Asia in 2016. Oceania closely trailed East Asia and even surpassed it in 2010. Meanwhile, South Asia and Central Asia placed fourth and fifth throughout the sample period.

By dimension, trade and investment integration with the region was led by Southeast Asia (Figure 4). Two dimensional indexes (trade and investment and money and finance) appear to exhibit some volatility in their integration trends. All subregions exhibited relatively highly volatile subindexes of money and finance integration. ${ }^{5}$ Moreover, the money and finance subindex peaked in 2008 for these subregions, reflecting the well-known statistical regularity of higher financial market correlations during crisis periods.

The remaining four subindexes displayed relatively stable movements across all Asia subregions. Southeast Asia scored highest in regional integration for the dimension of regional value chain until overtaken by Central Asia and East Asia in 2012. Oceania was the forerunner in regional integration for infrastructure and connectivity. Subregional variations in movement of people and institutional and social integration were particularly large across the sample period. Regional integration as reflected in the movement of people was dominated by Southeast Asia, while particularly weak in Central Asia. Finally, East Asia exhibited consistently higher institutional and social integration among other subregions of Asia, while the Pacific scored lowest on this front.

Figure 3: Overall Asia-Pacific Regional Cooperation and Integration Index-Asia Subregions

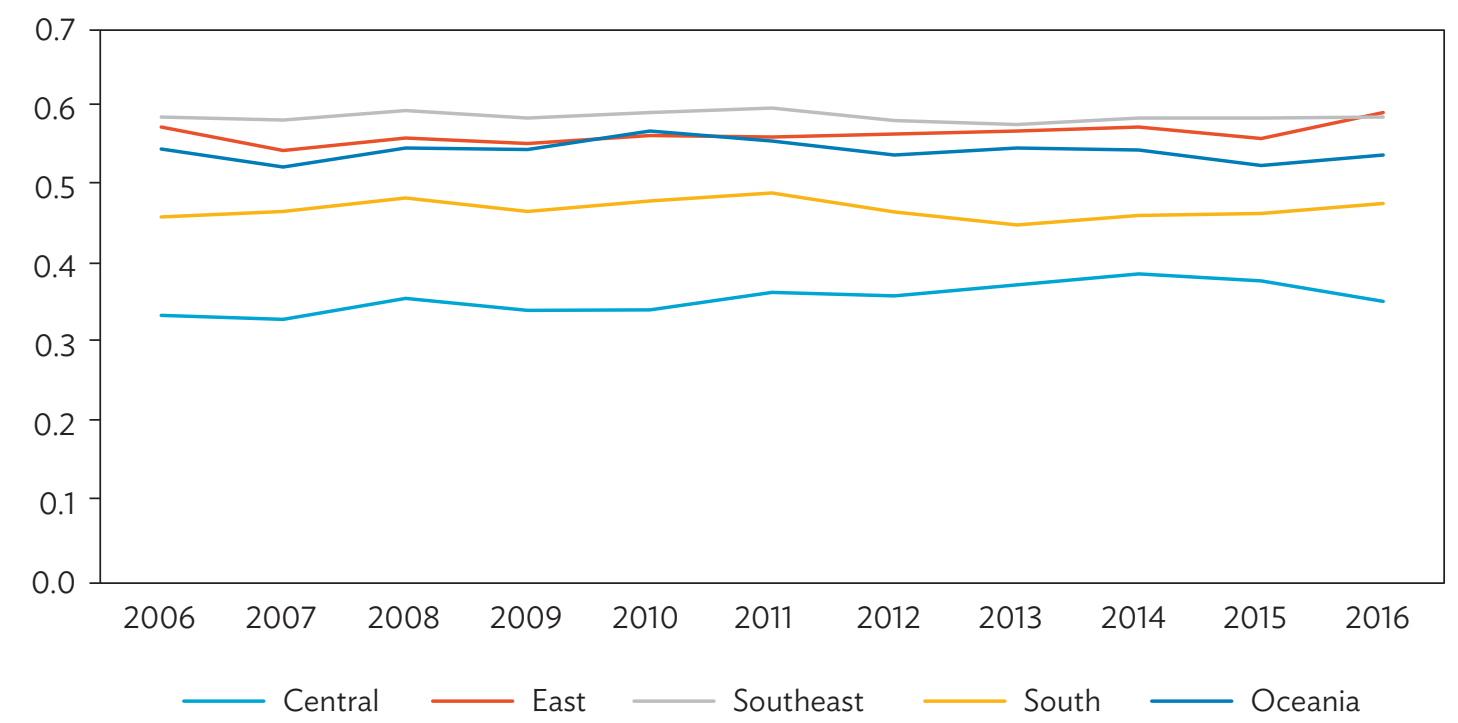

Source: Authors' calculations.

5 Except for the Pacific, for which the money and finance subindex could not be computed because of lack of data. 
Figure 4: Dimensional Subindexes-Asia Subregions
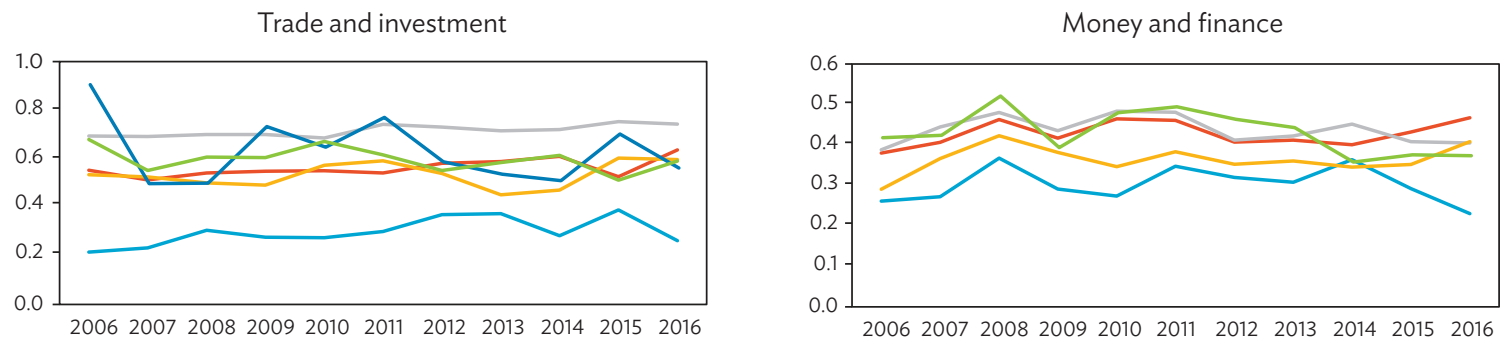

Regional value chain

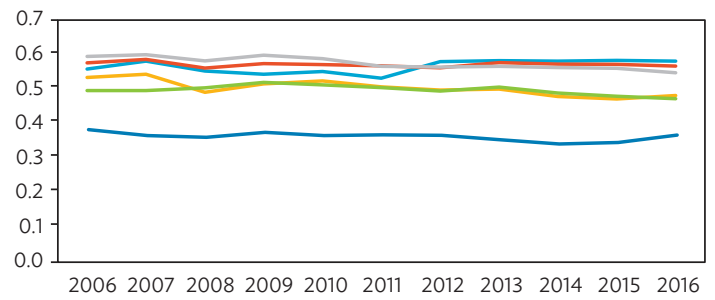

Infrastructure and connectivity

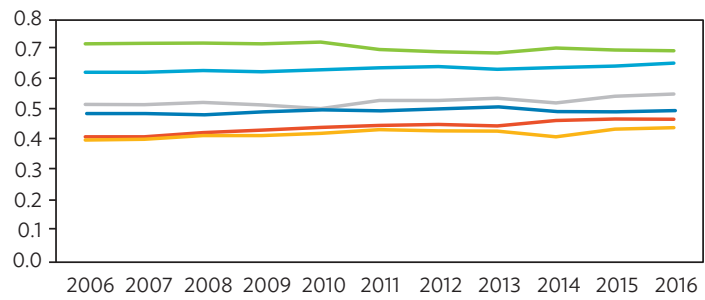

Movement of people

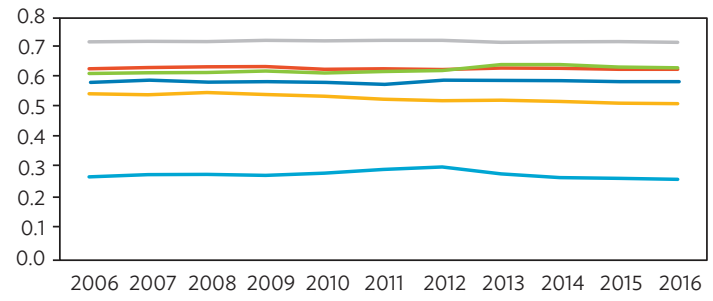

Institutional and social integration
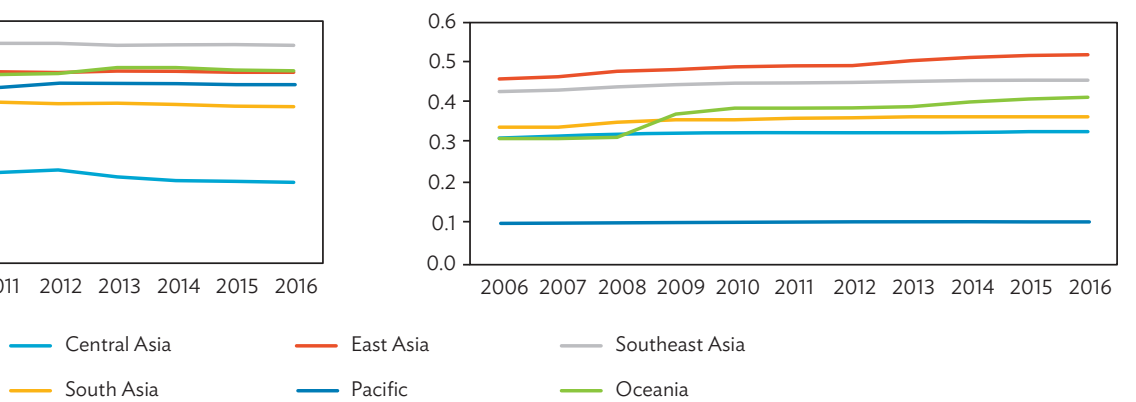

_ Southeast Asia

- Oceania

Source: Authors' calculations.

\section{Leaders in Regional Integration}

The time-varying ARCII enables examination of the evolution of regional integration of specific economies over time. This allows the leaders in regional integration from 2006 to 2016 to be determined. Of the 17 economies for which the ARCII could be computed for the years 2006 and 2016, 12 (more than 70\%) recorded positive progress in regional integration across the 11-year sample period (Figure 5). Georgia turned out to have made the most advancement, followed by the People's Republic of China; Japan; Bangladesh; India; Hong Kong, China; the Philippines; Kazakhstan; Thailand; Malaysia; Viet Nam; and Singapore. Meanwhile, five economies slipped in regional integration from 2006 to 2016. These were New Zealand, the Republic of Korea, Sri Lanka, Indonesia, and Australia. 


\section{Figure 5: Asia-Pacific Regional Cooperation and Integration Index, 2016 versus 2006-Selected Asian Economies}

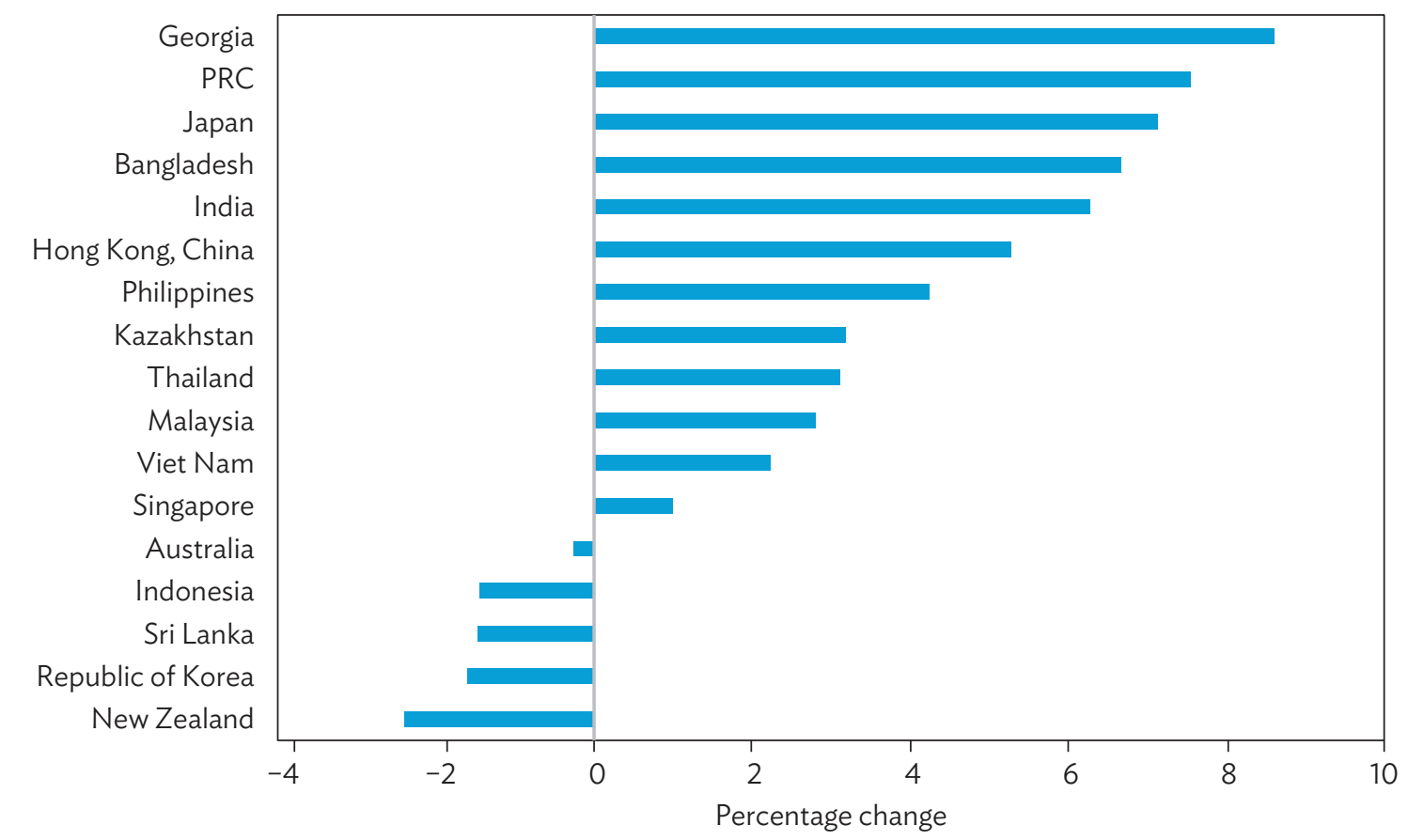

Source: Authors' calculations.

\section{CONSTRUCTION OF INTRASUBREGIONAL INTEGRATION INDEX}

The analysis of Asia subregions in the preceding section pertained to the integration of each subregion relative to the full sample Asian region. That is, the subregional indexes were computed by averaging the scores of the countries in each subregion. Therefore, strictly speaking, the subregional indexes represent a subregion's average regional integration with Asia. For example, East Asia's integration score would represent the average integration of all countries in East Asia with Asia, rather than integration taking place among the countries of East Asia.

Intrasubregional integration indexes are compiled in this section to gauge the extent of pure intrasubregional activity for each subregion. Specifically, integration within a particular subregion is computed, taking advantage of the panel with sufficient observations to compute the PCA weights for the selected subregion. The construction of the intrasubregional integration index parallels that of the regional integration index, except that ratios of intrasubregional activity (in place of intraregional activity) to total activity are utilized and that normalization, percentile transformation, and weightings through panel PCA are performed for each subregion. ${ }^{6}$

Table 5 reports the panel PCA-derived weights for the intrasubregional integration indexes compiled for East, Southeast, and South Asia where the number of observations is large enough to compute the weights for the intrasubregional indexes. Table 6 shows that data limitations make computation of the intrasubregional index possible only for East, Southeast, and South Asia.

6 Regression imputation was undertaken at the regional level to meet the required number of observations. Regression results are reported in Column III of the appendix table. 
Table 5: Panel Principal Component Analysis-Derived Weights-Asia Intraregional versus
Intrasubregional Integration Indexes

\begin{tabular}{lcccc}
\hline & $\begin{array}{c}\text { Intraregional } \\
\text { Integration } \\
\text { Index }\end{array}$ & \multicolumn{3}{c}{$\begin{array}{c}\text { Intrasubregional } \\
\text { Integration } \\
\text { Index }\end{array}$} \\
\cline { 2 - 5 } Dimension & Asia & East Asia & Southeast Asia & South Asia \\
\hline Trade and investment & 0.187 & 0.156 & 0.167 & 0.139 \\
Money and finance & 0.116 & 0.166 & 0.170 & 0.179 \\
Regional value chain & 0.156 & 0.167 & 0.154 & 0.155 \\
Infrastructure and connectivity & 0.172 & 0.175 & 0.175 & 0.165 \\
Movement of people & 0.186 & 0.171 & 0.186 & 0.181 \\
Institutional and social integration & 0.182 & 0.165 & 0.148 & 0.179 \\
Sum & 1.000 & 1.000 & 1.000 & 1.000 \\
\hline
\end{tabular}

Source: Authors' calculations.

Table 6: Intrasubregional Integration Index, 2006-2016-Country Coverage

\begin{tabular}{lll}
\hline East Asia & Southeast Asia & South Asia \\
\hline People's Republic of China & Cambodia & Bangladesh \\
Hong Kong, China & Indonesia & India \\
Japan & Lao People's Democratic Republic & Maldives \\
Republic of Korea & Malaysia & Nepal \\
Mongolia & Philippines & Pakistan \\
& Singapore & Sri Lanka \\
& Thailand & \\
\hline
\end{tabular}

Source: Authors' compilation.

In East Asia, infrastructure and connectivity shows the highest weight, and trade and investment the lowest. Movement of people gets the largest share in Southeast Asia and South Asia's intrasubregional integration indexes. Institutional and social integration and trade and investment are apportioned the least weights for Southeast Asia and South Asia.

\section{The Overall Intrasubregional Integration Index}

Over the sampled years, intrasubregional integration was highest for East Asia, except for 2009, when it was overtaken by Southeast Asia (Figure 6). South Asia lagged the two subregions during the full sample period.

Infrastructure and connectivity as well as institutional and social integration appeared to be the driving forces behind integration of the countries within each of the East Asia, Southeast Asia, and South Asia subregions (Figure 7). Movement of people also made an increasingly greater contribution to integration within Southeast Asia after 2012. 
Figure 6: Intrasubregional Integration Indexes

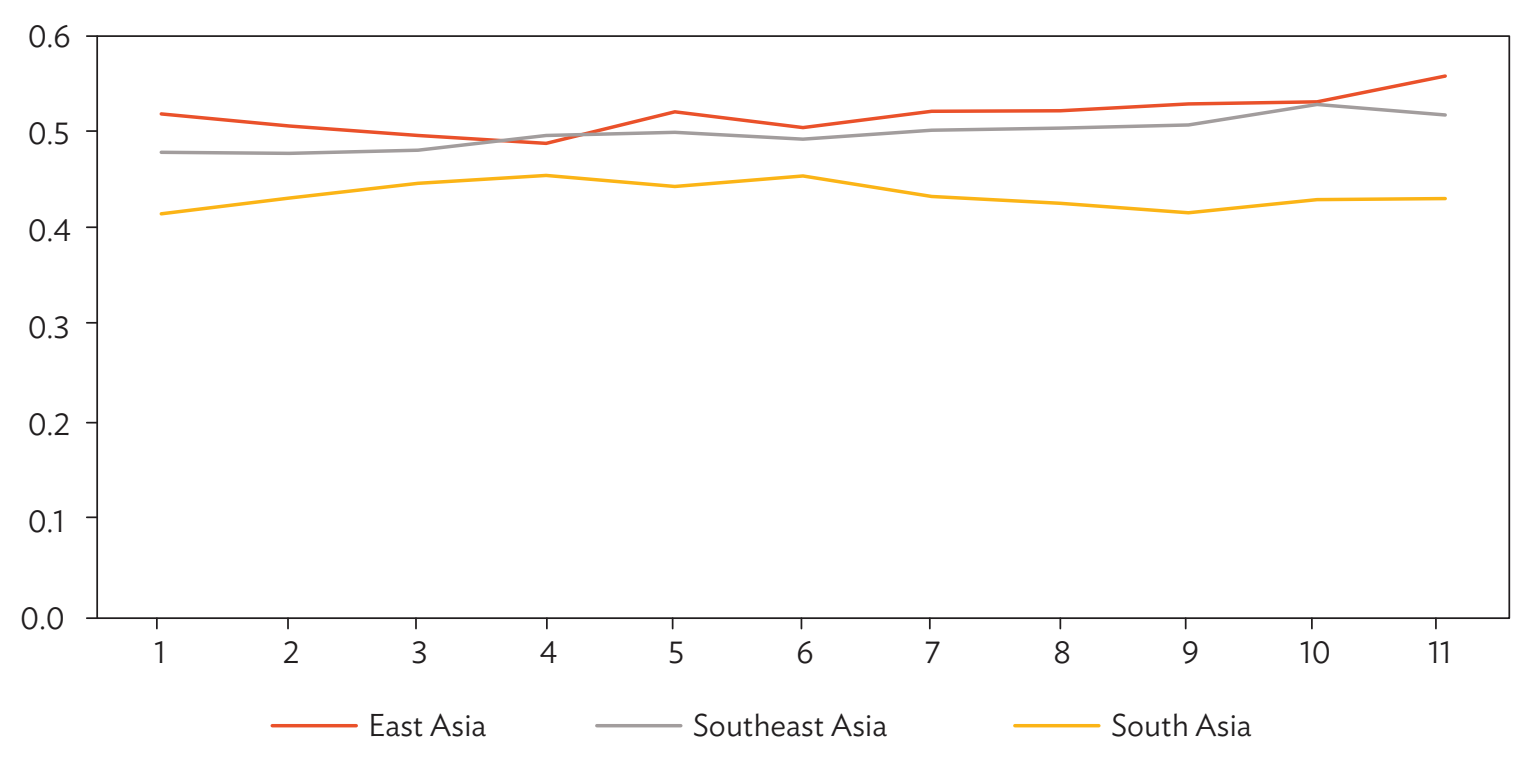

Source: Authors' calculations.

By dimension, Dimension III (regional value chain) and IV (infrastructure and connectivity) scored highly for intrasubregional integration in all three subregions (Figure 8). Dimension I (trade and investment) and II (money and finance) scored relatively low. The low score for trade and investment may be surprising, but it is natural considering that countries in these subregions (East, Southeast, and South Asia) trade and invest largely across other subregions rather than within themselves only. ${ }^{7}$ Substantial subregional variations in the degree of intrasubregional integration were observed for Dimension II (money and finance) and Dimension VI (institutional and social integration).

7 The relatively greater intersubregional versus intrasubregional integration in trade and investment can also be seen from the higher magnitude of trade and investment subindex in Figure 4. 
Figure 7: Dimensional Contribution to Intrasubregional Integration Indexes
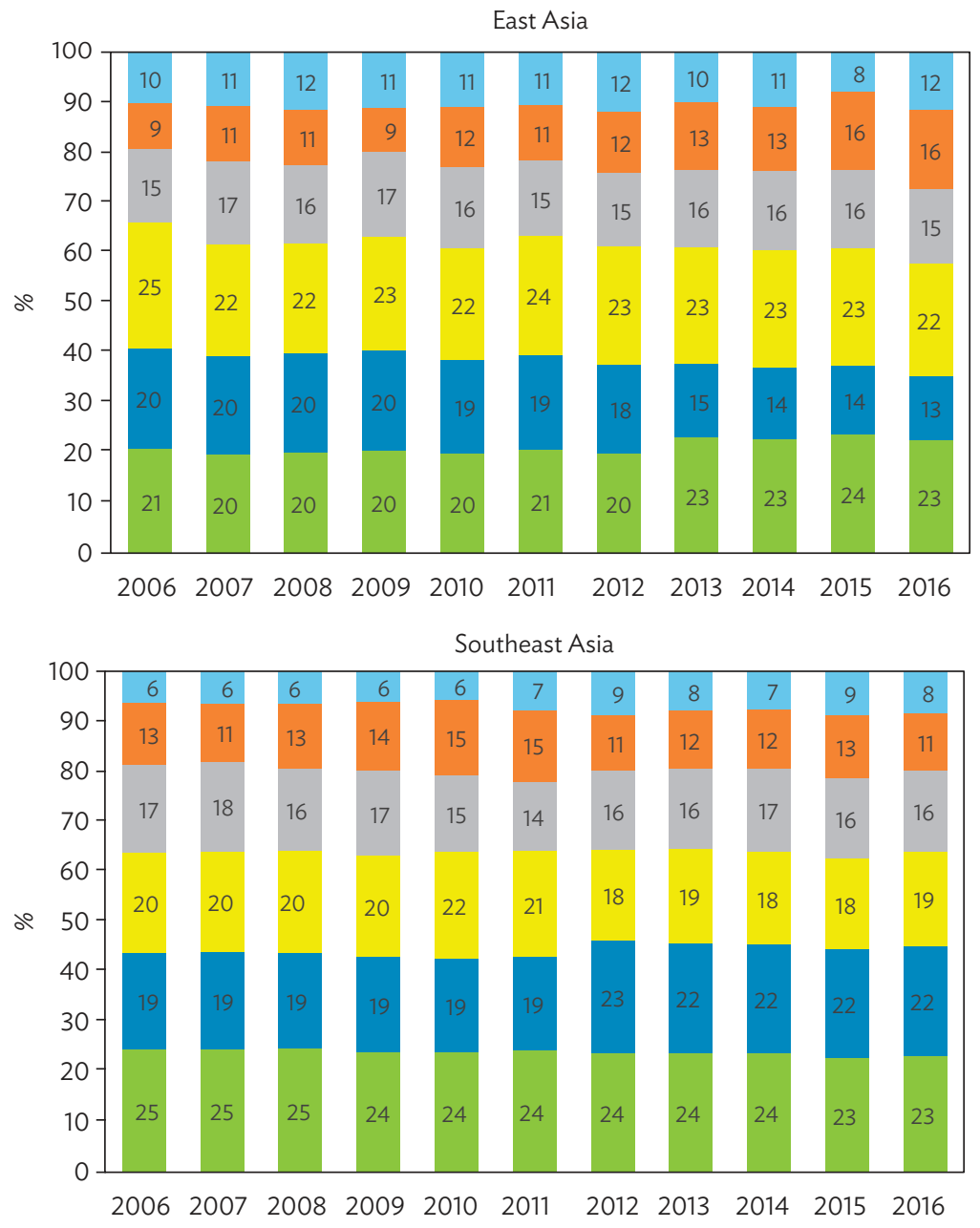

South Asia

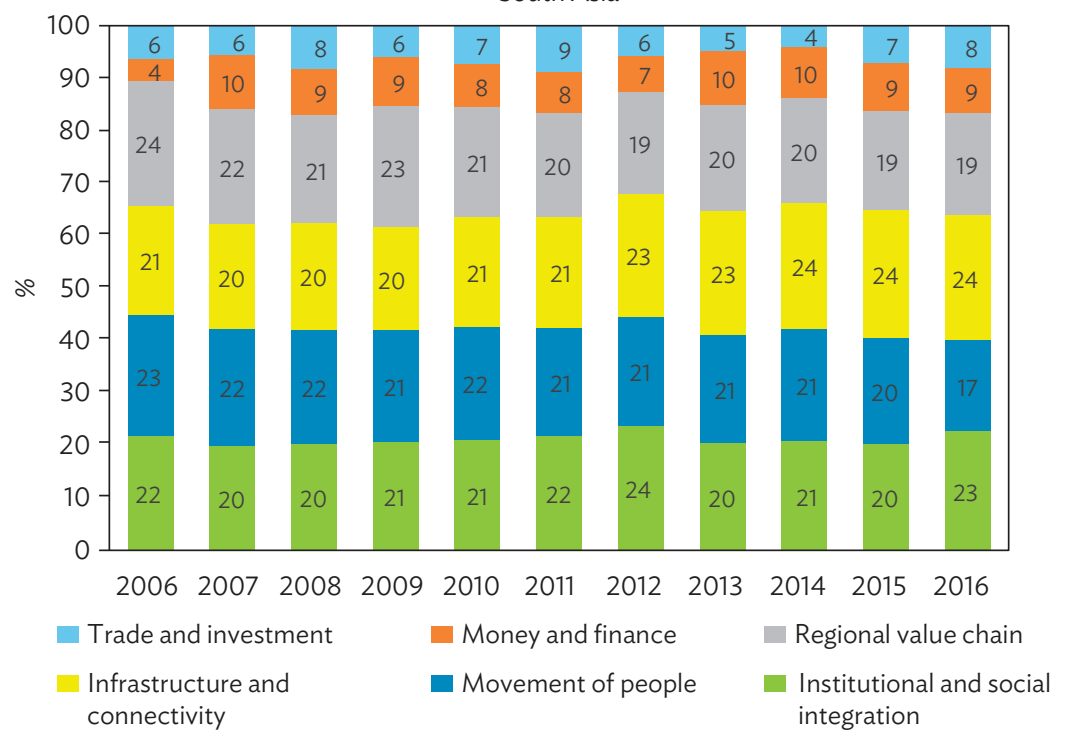

Source: Authors' calculations. 


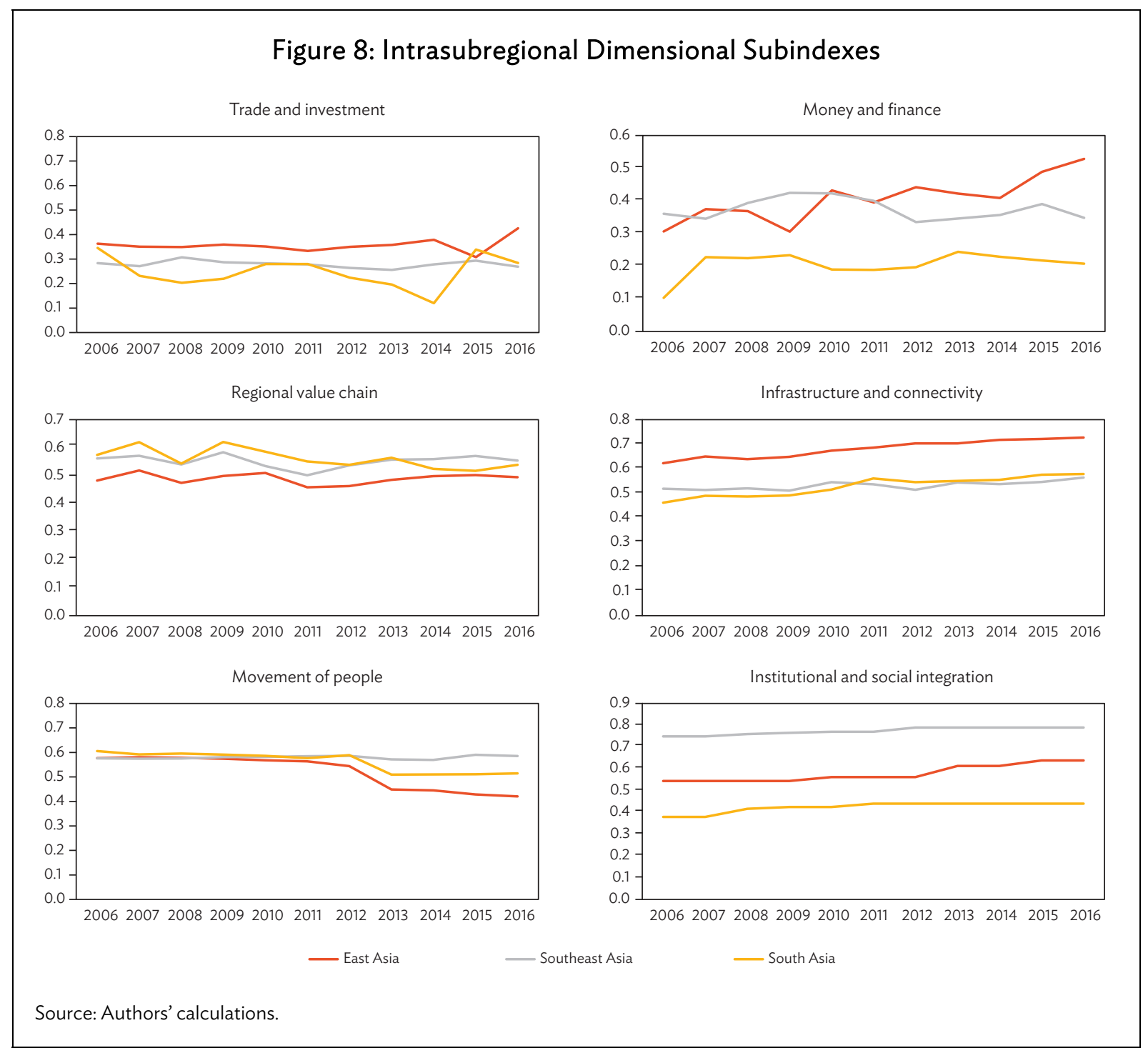

In Dimension I (trade and investment), East Asia led the intrasubregional integration during the entire sample period, except for 2015. The subregion also consistently scored high for money and finance integration from 2012 onwards. South Asia took precedence in intrasubregional value chain integration until 2013 but was then surpassed by Southeast Asia. Intrasubregional integration in terms of infrastructure and connectivity was clearly dominated by East Asia. Southeast Asia led intrasubregional integration in the movement of people from 2013 onwards and dominated institutional and social integration across the entire sample period. 


\section{COMPARISON WITH OTHER REGIONS}

Corresponding integration indexes were built for other regions of the world, utilizing all available information for all the economies and years in the sample period (i.e., 158 economies for 2006-2016) in the data imputation, normalization, percentile transformation, and weighting and aggregation. ${ }^{8}$

Figure 9 compares the panel PCA-derived weights for Asia, the European Union (EU), Latin America, and Africa. The EU appears to have the most evenly distributed shares for the six dimensions of its regional integration index. Institutional and social integration and regional value chain integration account for the largest weight in the regional indexes of Latin America and Africa, respectively.

Across time, the EU clearly is the most advanced in regional integration. Asia comes second and close to the global average (Figure 10). Latin America places overall third, though was overtaken by Africa in 2009.

\section{Figure 9: Summary of Panel Principal Component Analysis-Derived Weights} -Asia versus Other Regions

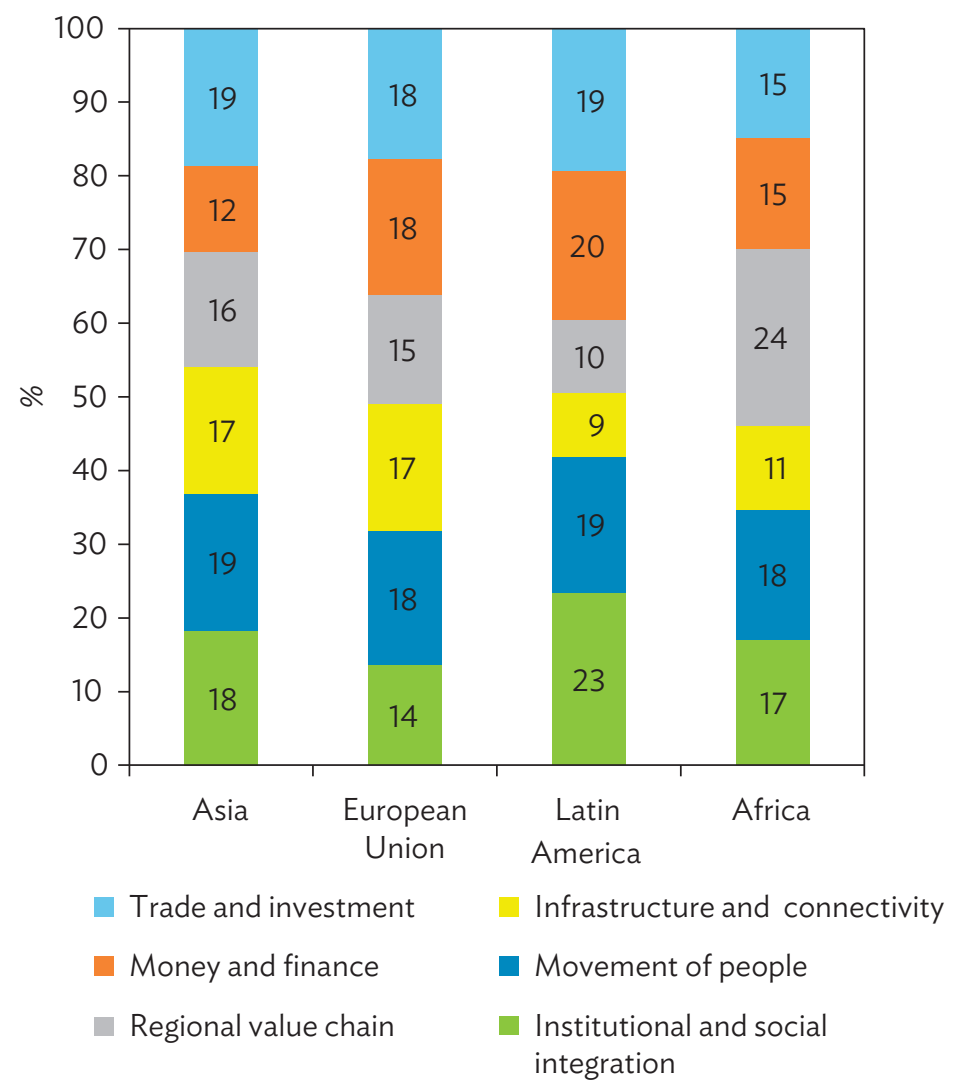

Source: Authors' calculations.

8 Results of the regression runs for data imputation are listed in Column II of the appendix table. Meanwhile, as in Huh and Park (2018), the United States and Canada are included as part of the global economy in the panel normalization. 


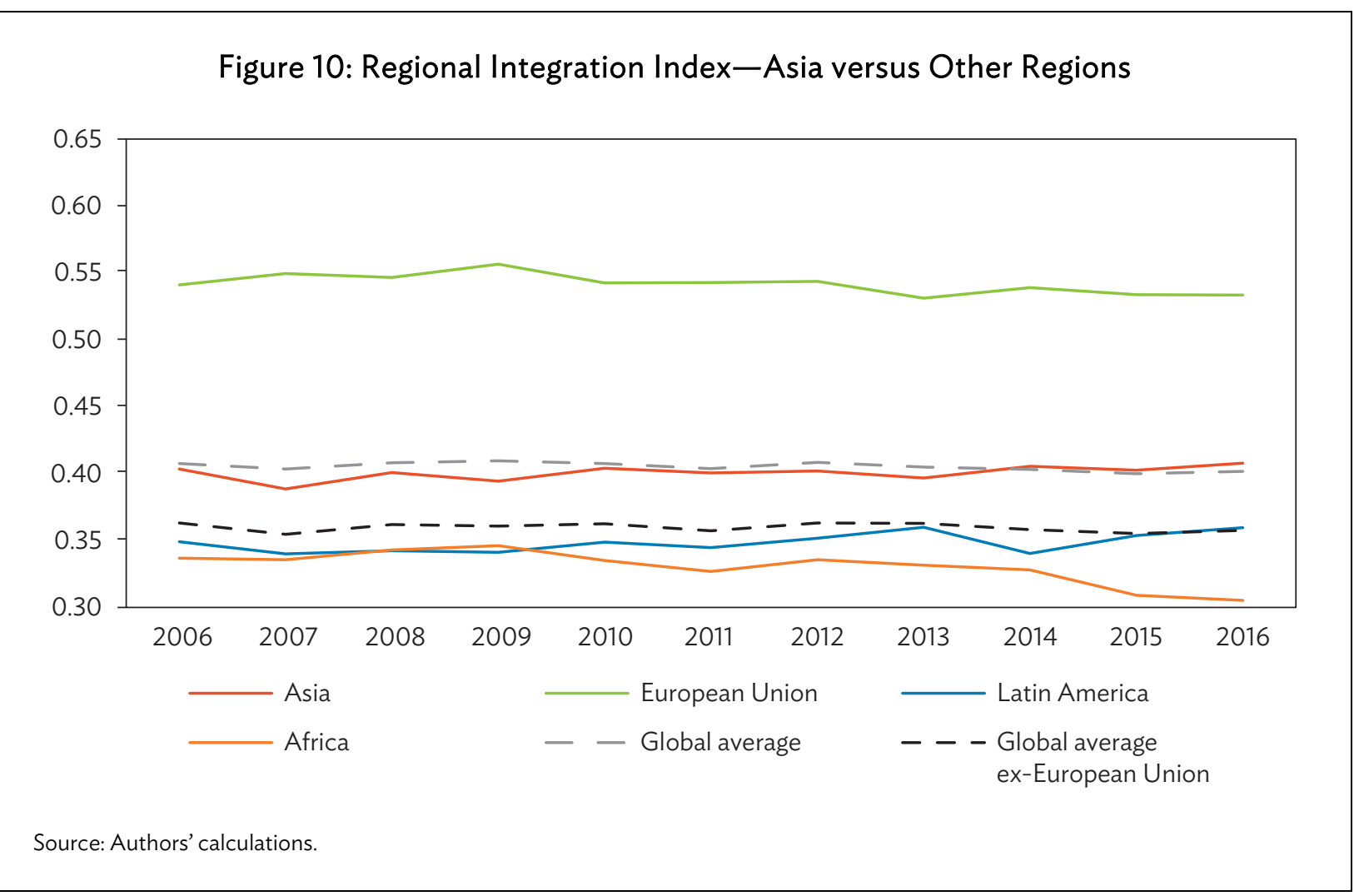

Infrastructure and connectivity appears to be the most forceful and stable foundation for regional integration in Asia. But over time, trade and investment have strengthened as a major contributor to regional integration, compensating for a modest weakening in movement of people (Figure 11). In the EU, contributions of all dimensions are broadly balanced, although money and finance, infrastructure and connectivity, movement of people, and institutional and social integration contribute a bit more than the other two measures. Institutional and social integration support regional integration the most in Latin America, while advances in the regional value chain contributes the most to regional integration in Africa.

Figure 12 shows that, over the years, EU consistently scores the highest in all dimensions of regional integration except for trade and investment, where Asia caught up with the EU from 2010 onward. The EU's money and finance integration has also visibly weakened since its peak in 2009, reflecting the impact of the euro crisis.

\section{Rankings}

The time-consistent panel PCA allows tracing both absolute and relative changes in ARCII over time. Specifically, changes in ARCII scores across periods indicate the absolute evolution in regional integration performance while changes in ARCII rank over time indicate relative evolution. Table 7 summarizes the rankings in regional integration index for individual economies from 2006 to 2016 with shading according to the region in which they belong. While most EU economies congregate at the high ranks, Asian economies, particularly Singapore and Malaysia, can be seen climbing higher in international ranking and breaking through the spots dominated by the EU. 
Figure 11: Dimensional Contribution to Overall Regional Integration Index -Asia versus Other Regions

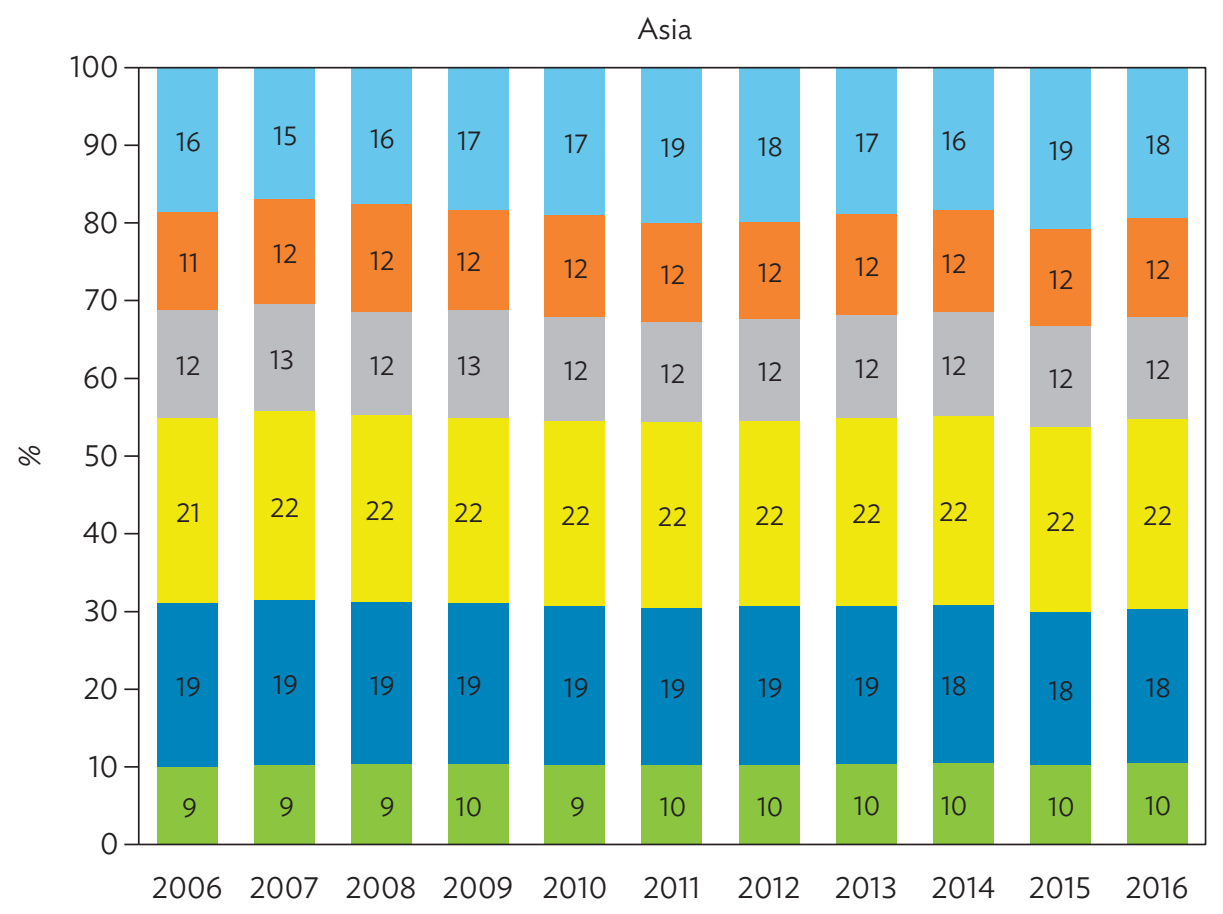

European Union

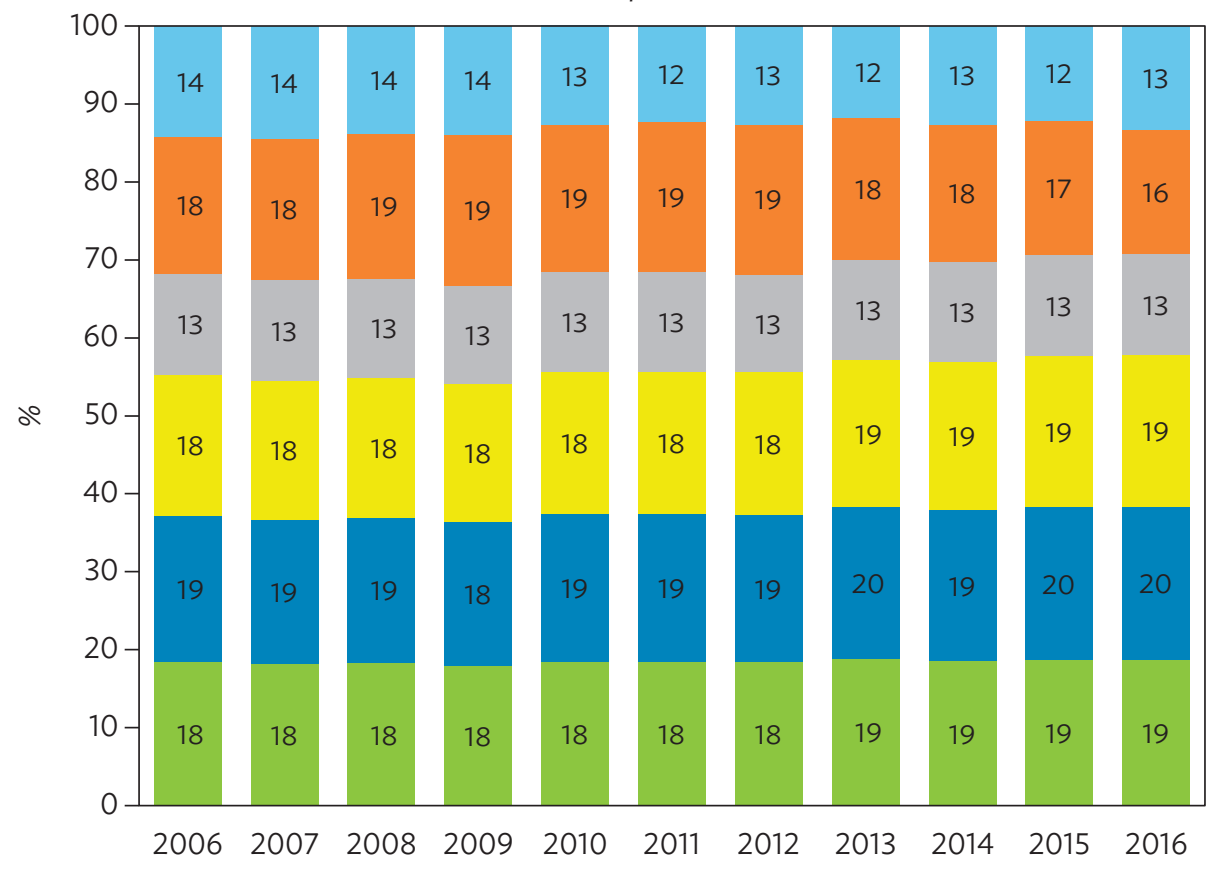


Figure 11 continued

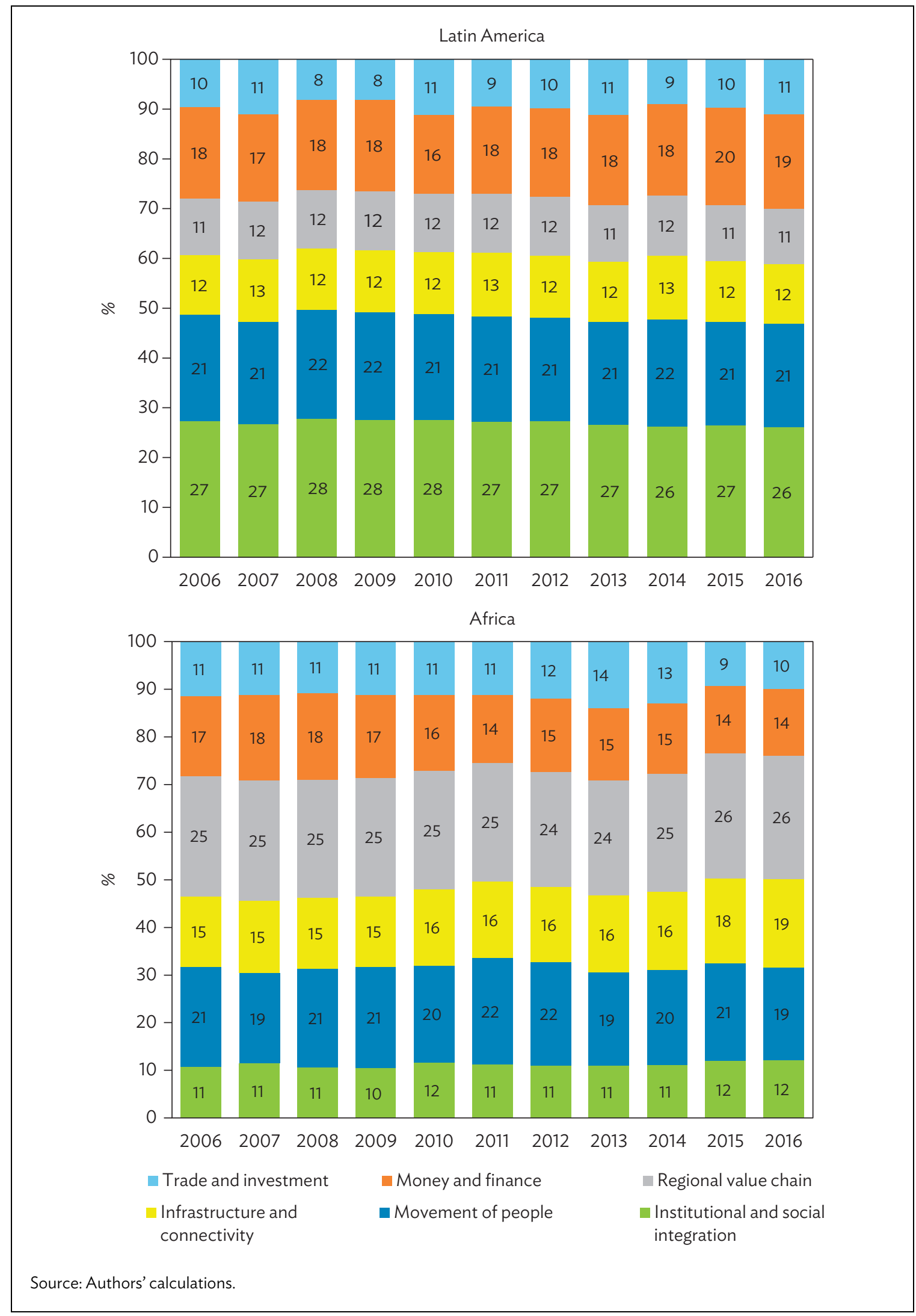




\section{Figure 12: Dimensional Subindexes-Asia versus Other Regions (based on worldwide normalization)}
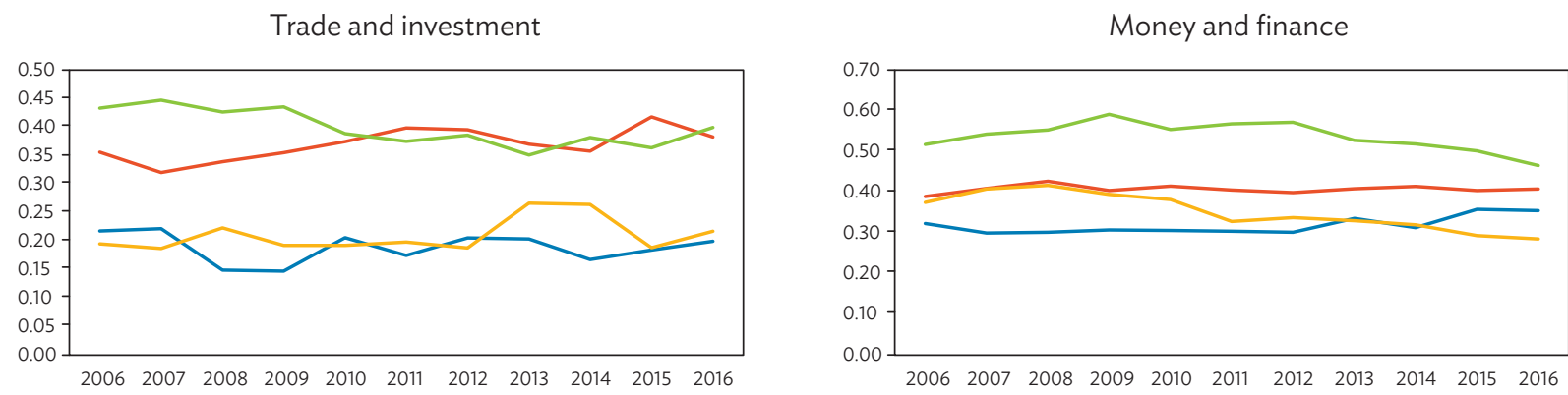

Regional value chain

Infrastructure and connectivity
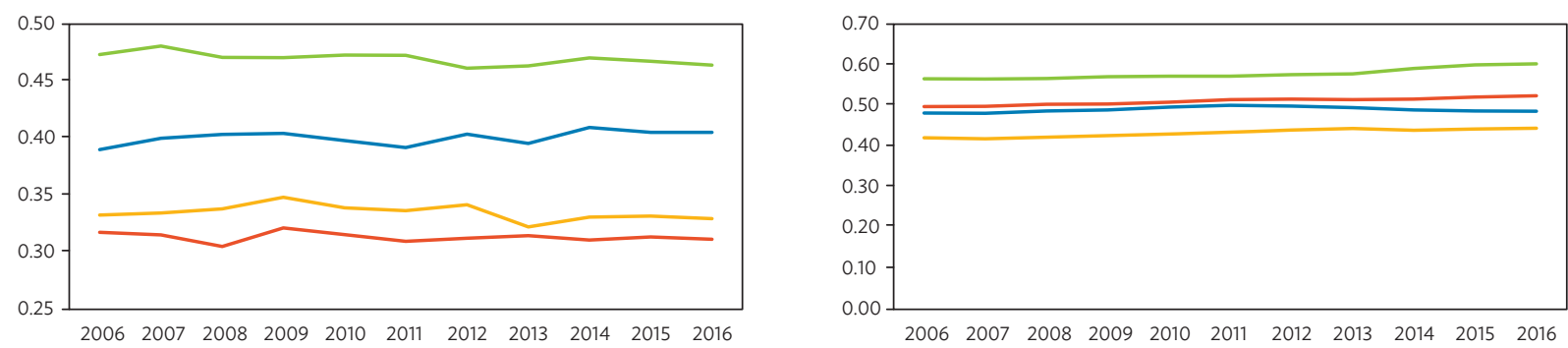

Movement of people
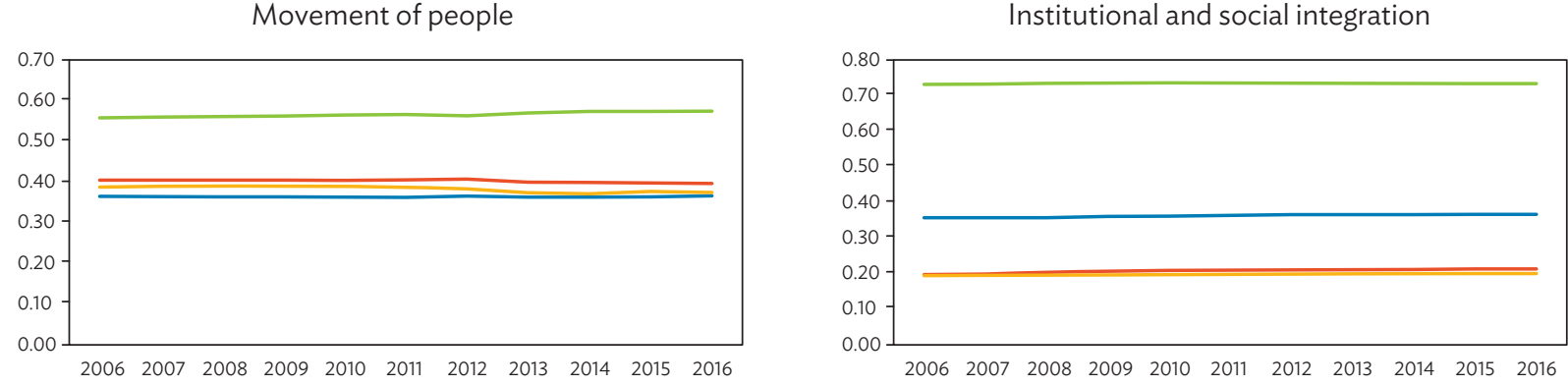

- Asia European Union

- Latin America — Africa

Source: Authors' calculations. 
Table 7: Economy Rankings, Regional Integration Indexes

\begin{tabular}{|c|c|c|c|c|c|c|c|c|c|c|c|c|c|}
\hline Rank & 2006 & 2007 & 2008 & 2009 & 2010 & 2011 & 2012 & 2013 & 2014 & 2015 & & 2016 & \\
\hline $1 s$ & Slovak Republic & 0.615 Czech Republic & 0.617 Czech Republic & 0.614 Slovak Republic & 0.623 Czech Republic & 0.616 Romania & 0.614 Czech Republic & 0.624 Slovak Republic & 0.599 Czech Republic & 0.610 Slovak Republic & 0.600 & Czech Republic & 0.617 \\
\hline 2 & Czech Republic & 0.597 Slovak Republic & 0.607 Slovak Republic & 0.602 Romania & 0.613 Slovak Republic & 0.606 Czech Republic & 0.612 Slovak Republic & 0.610 Romania & 0.599 Slovak Republic & 0.597 Romania & 0.590 & Slovak Republic & 0.616 \\
\hline 31 & Poland & 0.594 Belgium & 0.594 Poland & 0.599 Poland & 0.608 Poland & 0.599 Slovak Republic & 0.601 Poland & 0.598 Poland & 0.596 Poland & 0.592 Poland & 0.589 & Poland & 0.599 \\
\hline 4 & Hungary & 0.591 Hungary & 0.589 Hungary & 0.594 Czech Republic & 0.607 Romania & 0.593 Poland & 0.600 Hungary & 0.593 Czech Republic & 0.586 Romania & 0.581 Czech Republic & 0.589 & Belgium & 0.587 \\
\hline 5 & Luxembourg & 0.579 Poland & 0.586 Romania & 0.594 Belgium & 0.597 Hungary & 0.578 Hungary & 0.581 Belgium & 0.589 Portugal & 0.562 Slovenia & 0.572 Belgium & 0.574 & Romania & 0.568 \\
\hline 6 & Romania & 0.575 Romania & 0.584 Luxembourg & 0.573 Hungary & 0.583 Luxembourg & 0.563 Belgium & 0.578 Romania & 0.585 Luxembourg & 0.561 Luxembourg & 0.571 Austria & 0.573 & Luxembourg & 0.562 \\
\hline 7 & Belgium & 0.573 Austria & 0.574 Sweden & 0.567 Portugal & 0.581 Portugal & 0.561 Austria & 0.571 Luxembourg & 0.575 Hungary & 0.557 Austria & 0.570 Hungary & 0.562 & Hungary & 0.560 \\
\hline 8 & Portugal & 0.566 Finland & 0.566 Belgium & 0.561 Luxembourg & 0.572 Finland & 0.556 Finland & 0.571 Slovenia & 0.571 Austria & 0.552 Hungary & 0.561 Finland & 0.551 & Lithuania & 0.553 \\
\hline 91 & Lithuania & 0.563 Portugal & 0.565 Austria & 0.561 Sweden & 0.567 Belgium & 0.555 Portugal & 0.555 Finland & 0.558 Latvia & 0.549 Estonia & 0.555 Luxembourg & 0.546 & Estonia & 0.552 \\
\hline 10 & Sweden & 0.553 Luxembourg & 0.558 Portugal & 0.559 Slovenia & 0.565 Austria & 0.545 Luxembourg & 0.552 Portugal & 0.554 Belgium & 0.541 Bulgaria & 0.555 Slovenia & 0.544 & Sweden & 0.547 \\
\hline 11 & Austria & 0.545 Latvia & 0.558 Estonia & 0.556 Estonia & 0.562 Latvia & 0.544 Latvia & 0.550 Austria & 0.551 Bulgaria & 0.537 Latvia & 0.554 Sweden & 0.542 & Finland & 0.538 \\
\hline 12 & Slovenia & 0.542 Sweden & 0.554 Lithuania & 0.554 Finland & 0.554 Sweden & 0.543 Slovenia & 0.548 Estonia & 0.549 Germany & 0.536 Sweden & 0.554 Latvia & 0.540 & Portugal & 0.538 \\
\hline 13 & Finland & 0.538 Lithuania & 0.553 Netherlands & 0.551 Netherlands & 0.552 Lithuania & 0.541 Estonia & 0.544 Sweden & 0.549 Denmark & 0.536 Belgium & 0.552 Estonia & 0.537 & Austria & 0.537 \\
\hline $14 \mathrm{I}$ & Netherlands & 0.527 Ireland & 0.551 Ireland & 0.544 Lithuania & 0.552 Ireland & 0.538 Netherlands & 0.543 Germany & 0.541 Slovenia & 0.535 Finland & 0.550 Germany & 0.529 & Italy & 0.537 \\
\hline 15 & Greece & 0.527 Germany & 0.546 Germany & 0.540 Denmark & 0.551 Estonia & 0.538 Germany & 0.543 Lithuania & 0.528 Finland & 0.534 Germany & 0.545 Netherlands & 0.522 & Bulgaria & 0.537 \\
\hline 16 & Estonia & 0.527 Slovenia & 0.540 Denmark & 0.538 Austria & 0.551 Germany & 0.538 Sweden & 0.541 Netherlands & 0.526 Lithuania & 0.523 Lithuania & 0.533 Lithuania & 0.521 & Slovenia & 0.526 \\
\hline 17 & Germany & 0.524 Spain & 0.533 Slovenia & 0.537 Bulgaria & 0.546 Netherlands & 0.536 Ireland & 0.533 Italy & 0.525 Estonia & 0.521 Portugal & 0.530 Spain & $0.518 \quad 1$ & Netherlands & 0.524 \\
\hline 18 & Latvia & 0.521 Estonia & 0.533 Latvia & 0.535 Ireland & 0.542 Bulgaria & 0.534 Bulgaria & 0.530 Bulgaria & 0.525 Netherlands & 0.516 France & 0.529 Greece & 0.517 & Germany & 0.524 \\
\hline 19 & Denmark & 0.521 Denmark & 0.532 Finland & 0.532 Germany & 0.540 Spain & 0.532 Greece & 0.526 Greece & 0.521 Italy & 0.515 Spain & 0.527 Bulgaria & 0.517 & France & 0.523 \\
\hline 20 & Bulgaria & 0.517 Italy & 0.527 Spain & 0.530 Spain & 0.539 Denmark & 0.531 France & 0.526 Spain & 0.520 France & 0.513 Netherlands & 0.524 Portugal & 0.516 & Latvia & 0.515 \\
\hline 211 & Italy & 0.515 France & 0.526 Bulgaria & 0.523 Greece & 0.536 Slovenia & 0.526 Spain & 0.522 Denmark & 0.518 Sweden & 0.513 Ireland & 0.513 Italy & 0.515 & Spain & 0.512 \\
\hline 22 & France & 0.513 Greece & 0.522 Greece & 0.519 Italy & 0.533 Greece & 0.520 Italy & 0.513 France & 0.516 Spain & 0.511 Italy & 0.512 France & 0.515 & Malaysia & 0.510 \\
\hline 231 & Ireland & 0.508 Netherlands & 0.514 France & 0.519 France & 0.529 France & 0.516 Denmark & 0.511 Ireland & 0.513 Ireland & 0.510 Denmark & 0.510 Denmark & 0.509 & Denmark & 0.497 \\
\hline $24 s$ & Spain & 0.504 Malta & 0.503 Italy & 0.510 Latvia & 0.524 Italy & 0.506 Malaysia & 0.492 Malaysia & 0.503 Malaysia & 0.497 Malaysia & 0.503 Malaysia & 0.505 & Greece & 0.495 \\
\hline 25 & Cyprus & 0.498 Bulgaria & 0.503 United Kingdom & 0.497 Malta & 0.508 Malta & 0.492 Thailand & 0.485 Malta & 0.503 Greece & 0.480 Greece & 0.489 Ireland & 0.495 & Singapore & 0.493 \\
\hline 26 & United Kingdom & 0.497 Cyprus & 0.500 Cyprus & 0.479 Cyprus & 0.500 Singapore & 0.487 Lithuania & 0.484 Latvia & 0.493 PRC & 0.470 United Kingdom & 0.475 Singapore & 0.484 & PRC & 0.484 \\
\hline 271 & Malaysia & 0.491 United Kingdom & 0.495 Malaysia & 0.478 United Kingdom & 0.491 Malaysia & 0.484 Singapore & 0.479 Cyprus & 0.477 United Kingdom & 0.469 Singapore & 0.473 Cyprus & 0.476 & Ireland & 0.481 \\
\hline $28 s$ & Singapore & 0.480 Malaysia & 0.488 Singapore & 0.477 Singapore & 0.478 New Zealand & 0.474 PRC & 0.474 Thailand & 0.476 Thailand & 0.467 PRC & 0.470 Thailand & 0.475 & United Kingdom 0 & 0.480 \\
\hline 291 & Malta & 0.473 Singapore & 0.472 Malta & 0.469 Malaysia & 0.475 Cyprus & 0.473 Cyprus & 0.472 Singapore & 0.473 Singapore & 0.465 Thailand & 0.467 United Kingdom & 0.473 & Hong Kong, China O & 0.475 \\
\hline $30 \mathrm{r}-\mathrm{k}(\mathrm{k})$ & Korea, Republic of & 0.452 Namibia & 0.454 PRC & 0.463 Korea, Republic of & 0.462 PRC & 0.470 United Kingdom & 0.471 United Kingdom & 0.472 Korea, Republic of & 0.457 Cyprus & 0.462 PRC & 0.472 & Thailand 0 & 0.473 \\
\hline 31 & Thailand & 0.451 Thailand & 0.450 Korea, Republic of & 0.460 Swaziland & 0.462 United Kingdom & 0.468 Korea, Republic of & 0.470 PRC & 0.466 Swaziland & 0.456 Korea, Republic of & $\begin{array}{l}0.461 \text { Lao People's } \\
\text { Democratic } \\
\text { Republic }\end{array}$ & 0.468 & Japan & 0.456 \\
\hline 32 & Hong Kong, China & 0.445 PRC & 0.447 Hong Kong, China & 0.457 PRC & 0.462 Korea, Republic of & 0.464 Malta & 0.464 Hong Kong, China & 0.457 Hong Kong, China & 0.452 New Zealand & 0.459 Korea, Republic of & 0.460 & Korea, Republic of $\mathrm{O}$ & $f 0.443$ \\
\hline 33 & PRC & 0.442 Korea, Republic of & 0.438 Thailand & 0.453 Thailand & 0.455 Thailand & 0.461 New Zealand & 0.458 Korea, Republic of & 0.455 New Zealand & $\begin{array}{l}0.448 \text { Lao People's } \\
\text { Democratic } \\
\text { Republic }\end{array}$ & 0.456 Malta & 0.455 & Cyprus $\quad 0$ & 0.442 \\
\hline 341 & New Zealand & 0.442 New Zealand & 0.427 Indonesia & 0.445 New Zealand & 0.448 Hong Kong, China & 0.458 Hong Kong, China & 0.445 Indonesia & 0.438 Malta & 0.447 Hong Kong, China & 0.454 Indonesia & 0.437 & Malta & 0.438 \\
\hline 351 & Malawi & 0.427 Hong Kong, China & 0.426 New Zealand & 0.440 Hong Kong, China & 0.447 Namibia & 0.451 Japan & 0.428 Japan & 0.431 Cyprus & 0.444 Indonesia & 0.437 Japan & 0.432 & New Zealand & 0.435 \\
\hline 361 & Indonesia & 0.427 Nicaragua & 0.423 Japan & 0.426 Japan & $0.433 \mathrm{Japan}$ & 0.431 Indonesia & $\begin{array}{l}0.427 \text { Lao People's } \\
\text { Democratic } \\
\text { Republic }\end{array}$ & $\begin{array}{l}0.421 \text { Lao People's } \\
\text { Democratic } \\
\text { Republic }\end{array}$ & 0.439 Malta & 0.429 Nicaragua & 0.426 & Viet $\mathrm{Nam}$ & 0.428 \\
\hline 371 & Nicaragua & 0.427 Indonesia & 0.420 Viet Nam & 0.423 Paraguay & 0.418 Indonesia & $\begin{array}{l}0.427 \text { Venezuela, } \\
\text { Republic } \\
\text { Bolivariana }\end{array}$ & 0.409 New Zealand & 0.420 Indonesia & 0.436 Japan & 0.428 Viet $\mathrm{Nam}$ & 0.415 & Indonesia & 0.428 \\
\hline $38 \mathrm{~J}$ & Japan & 0.424 Japan & 0.415 Swaziland & 0.418 Indonesia & 0.417 Viet Nam & 0.420 Swaziland & 0.405 St. Lucia & 0.415 Japan & 0.431 Viet Nam & 0.420 New Zealand & 0.4101 & Nepal & 0.426 \\
\hline $391-r a r a r$ & Uruguay & 0.421 Colombia & 0.389 Namibia & 0.412 Namibia & 0.405 Australia & 0.408 Namibia & 0.403 Viet Nam & 0.411 Panama & $0.409 \mathrm{Nepal}$ & 0.415 Hong Kong, China & 0.409 & St. Lucia & 0.423 \\
\hline
\end{tabular}


Table 7 continued

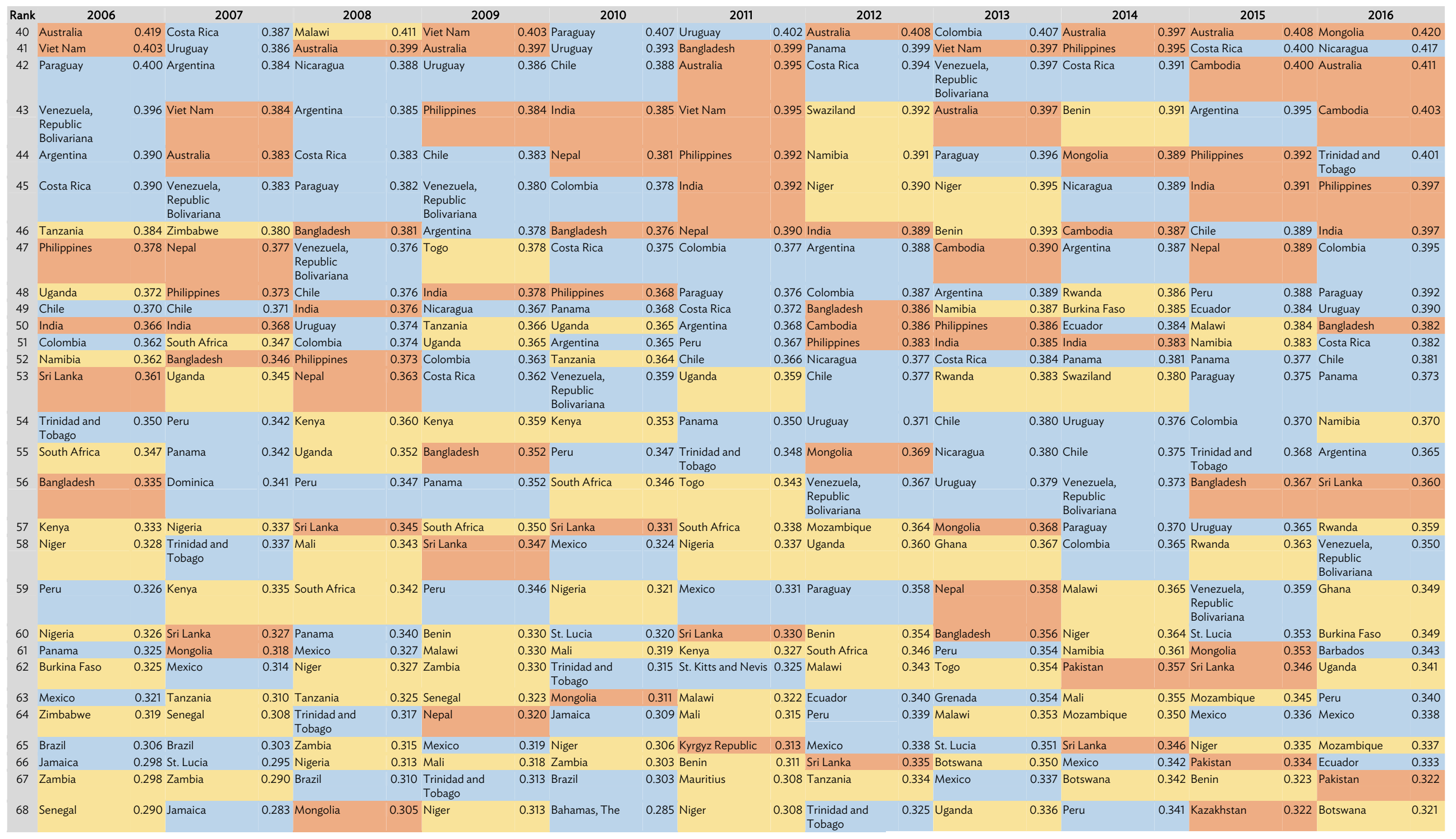


Table 7 continued

\begin{tabular}{|c|c|c|c|c|c|c|c|c|c|c|c|c|c|c|c|c|c|c|c|c|c|}
\hline Rank & 2006 & 2007 & & 2008 & & 2009 & & 20 & & 2011 & & 2012 & & 2013 & & 2014 & & 2015 & & 2016 & \\
\hline 69 & Kazakhstan & 0.286 Georgia & 0.266 & Jamaica & 0.290 & St. Lucia & 0.311 & Mauritius & 0.283 & Mongolia & 0.305 & Kenya & 0.323 & $\begin{array}{l}\text { Trinidad and } \\
\text { Tobago }\end{array}$ & 0.331 & $\begin{array}{l}\text { Trinidad and } \\
\text { Tobago }\end{array}$ & 0.341 & Kyrgyz Republic & 0.318 & South Africa & 0.313 \\
\hline 70 & Mauritius & 0.269 Kazakhstan & 0.259 & Georgia & 0.287 & Brazil & 0.309 & Kazakhstan & 0.280 & Brazil & 0.300 & Mali & 0.316 & Zambia & 0.331 & Kyrgyz Republic & 0.334 & Uganda & 0.317 & Brazil & 0.307 \\
\hline 71 & Georgia & $\begin{array}{l}0.257 \text { Antigua and } \\
\text { Barbuda }\end{array}$ & 0.252 & Senegal & 0.286 & $\begin{array}{l}\text { Antigua and } \\
\text { Barbuda }\end{array}$ & 0.302 & Senegal & 0.275 & St. Lucia & 0.285 & Georgia & 0.310 & Ecuador & 0.327 & Uganda & 0.334 & Zambia & 0.315 & Nigeria & 0.306 \\
\hline 72 & Bahamas, The & 0.255 Mauritius & 0.251 & Kazakhstan & 0.265 & Mongolia & 0.296 & Georgia & 0.264 & Tanzania & 0.279 & Senegal & 0.303 & South Africa & 0.325 & Zambia & 0.332 & South Africa & 0.315 & Jamaica & 0.306 \\
\hline 73 & $\begin{array}{l}\text { Antigua and } \\
\text { Barbuda }\end{array}$ & 0.247 Bahamas, The & 0.249 & Bahamas, The & 0.262 & Nigeria & 0.293 & & & Senegal & 0.277 & Brazil & 0.302 & Pakistan & 0.322 & Ghana & 0.326 & Ghana & 0.315 & Zambia & 0.305 \\
\hline 74 & & & & Mauritius & 0.257 & Kazakhstan & 0.279 & & & Jamaica & 0.276 & Jamaica & 0.297 & Georgia & 0.322 & Bahamas, The & 0.322 & Botswana & 0.314 & Grenada & 0.305 \\
\hline 75 & & & & $\begin{array}{l}\text { Antigua and } \\
\text { Barbuda }\end{array}$ & 0.247 & Mauritius & 0.275 & & & Georgia & 0.276 & Togo & 0.293 & Sri Lanka & 0.321 & South Africa & 0.320 & Brazil & 0.313 & Senegal & 0.302 \\
\hline 76 & & & & & & Jamaica & 0.265 & & & Zambia & 0.273 & Zambia & 0.289 & Mali & 0.320 & Brazil & 0.315 & Nigeria & 0.301 & Togo & 0.301 \\
\hline 77 & & & & & & Georgia & 0.263 & & & Bahamas, The & 0.267 & Mauritius & 0.287 & Mozambique & 0.318 & Bangladesh & 0.314 & Senegal & 0.295 & Mauritius & 0.293 \\
\hline 78 & & & & & & Bahamas, The & 0.246 & & & Kazakhstan & 0.263 & Nigeria & 0.286 & Jamaica & 0.316 & Togo & 0.309 & Togo & 0.293 & Bahamas, The & 0.290 \\
\hline 79 & & & & & & & & & & & & St. Kitts and Nevis & 0.285 & Brazil & 0.315 & Nigeria & 0.307 & Mali & 0.292 & Kazakhstan & 0.289 \\
\hline 80 & & & & & & & & & & & & Bahamas, The & 0.274 & Nigeria & 0.307 & Senegal & 0.303 & Morocco & 0.284 & Kenya & 0.286 \\
\hline 81 & & & & & & & & & & & & Kazakhstan & 0.264 & Senegal & 0.300 & St. Lucia & 0.303 & Tanzania & 0.284 & Morocco & 0.283 \\
\hline 82 & & & & & & & & & & & & Kyrgyz Republic & 0.263 & Mauritius & 0.296 & Algeria & 0.303 & Barbados & 0.283 & Georgia & 0.278 \\
\hline 83 & & & & & & & & & & & & & & Kazakhstan & 0.294 & Kazakhstan & 0.303 & $\begin{array}{l}\text { Antigua and } \\
\text { Barbuda }\end{array}$ & 0.282 & Tanzania & 0.274 \\
\hline 84 & & & & & & & & & & & & & & Kenya & 0.294 & $\begin{array}{l}\text { St. Vincent and } \\
\text { the Grenadines }\end{array}$ & 0.297 & Bahamas, The & 0.282 & Algeria & 0.260 \\
\hline 85 & & & & & & & & & & & & & & Morocco & 0.274 & Grenada & 0.287 & Mauritius & 0.281 & Kyrgyz Republic & 0.260 \\
\hline 86 & & & & & & & & & & & & & & Bahamas, The & 0.274 & Tanzania & 0.284 & Jamaica & 0.279 & Seychelles & 0.232 \\
\hline 87 & & & & & & & & & & & & & & Kyrgyz Republic & 0.266 & Georgia & 0.282 & Georgia & 0.272 & Cape Verde & 0.222 \\
\hline 88 & & & & & & & & & & & & & & Tanzania & 0.260 & Jamaica & 0.282 & Kenya & 0.266 & & \\
\hline 89 & & & & & & & & & & & & & & Algeria & 0.252 & Barbados & 0.281 & Algeria & 0.261 & & \\
\hline 90 & Legend: & & & & & & & & & & & & & Seychelles & 0.243 & Kenya & 0.279 & Seychelles & 0.228 & & \\
\hline 91 & & Asia & & & & & & & & & & & & & & Morocco & 0.273 & & & & \\
\hline 92 & & European Union & & & & & & & & & & & & & & Mauritius & 0.273 & & & & \\
\hline 93 & & Latin America & & & & & & & & & & & & & & $\begin{array}{l}\text { Antigua and } \\
\text { Barbuda }\end{array}$ & 0.246 & & & & \\
\hline 94 & & Africa & & & & & & & & & & & & & & Seychelles & 0.227 & & & & \\
\hline $\mathrm{N}$ & o. of economies & 73 & 73 & & 75 & & 78 & & 72 & & 78 & & 82 & & 90 & & 94 & & 90 & & 87 \\
\hline
\end{tabular}

PRC = People's Republic of China.

Source: Authors' calculations. 


\section{ROBUSTNESS CHECKS}

As a robustness check, a PCA is applied to data for 2014, which has the most number of observations for all countries. Similar analyses are conducted using both cross-section (year-specific) and panel PCA-derived weights. In addition, alternative runs without percentile transformation were made in order to determine the net effect of panel PCA-derived weights on the final results.

Table 8 summarizes the PCA-derived weights from various iterations. Overall, dimensional weights are broadly consistent between panel and cross-section PCAs with or without percentile transformation. For example, Dimensions I, IV, and $\mathrm{V}$ have relatively high weights, while Dimension II has the lowest weight for Asia across the alternative runs.

Figures 13-15 indicate relatively robust results for degrees of regional integration across different subregions in Asia, regardless of whether panel PCA and percentile transformation are applied. However, Figure 16 shows noticeable adjustments to the scores of the EU's money and finance subindex when percentile transformation is applied to min-max normalized indicators. This highlights the tendency of min-max scaling to skew transformed indicators toward extreme values that could lead to biased results. Percentile transformation tempers the sensitivity to outliers that is caused by min-max scaling. 
Table 8: Principal Component Analysis-Derived Weights

\begin{tabular}{|c|c|c|c|c|c|c|c|c|c|c|c|c|c|c|c|c|c|c|c|c|c|c|c|c|}
\hline \multirow[b]{3}{*}{ Dimension } & & \multicolumn{23}{|c|}{ Without Percentile Transformation } \\
\hline & & \multicolumn{12}{|c|}{ Panel PCA } & \multicolumn{11}{|c|}{ Cross-Section PCA } \\
\hline & & \multicolumn{3}{|c|}{1} & \multicolumn{2}{|l|}{ II } & III & \multicolumn{2}{|r|}{ IV } & \multicolumn{2}{|c|}{ v } & \multicolumn{2}{|c|}{ VI } & \multicolumn{2}{|l|}{1} & \multicolumn{2}{|l|}{ II } & \multicolumn{2}{|l|}{ III } & \multicolumn{2}{|l|}{ IV } & V & \multicolumn{2}{|c|}{$\mathrm{VI}$} \\
\hline \multirow[t]{2}{*}{ Asia } & & & & & & \multirow{2}{*}{\multicolumn{2}{|c|}{0.169}} & & & \multirow{2}{*}{\multicolumn{2}{|c|}{0.183}} & & & & & & & \multirow{2}{*}{\multicolumn{2}{|c|}{0.176}} & & & & & \\
\hline & & \multicolumn{3}{|c|}{0.170} & 0.119 & & & & 0.177 & & & \multicolumn{2}{|c|}{0.182} & \multicolumn{2}{|c|}{0.172} & \multicolumn{2}{|l|}{0.108} & & & \multicolumn{2}{|l|}{0.192} & \multicolumn{2}{|l|}{0.180} & 0.172 \\
\hline European Union & & & 0.157 & & 0.202 & & 0.171 & & 0.159 & 0.1 & & & .164 & 0.1 & & 0.189 & & 0.180 & & 0.165 & & 0.142 & & 0.175 \\
\hline Africa & & & 0.171 & & 0.114 & & 0.205 & & 0.207 & 0.1 & & & 0.155 & 0.1 & & 0.161 & & 0.166 & & 0.180 & & 0.185 & & 0.152 \\
\hline & & & & & & & & & & & With $\mathrm{F}$ & ercentile & Transfo & nation & & & & & & & & & & \\
\hline & & & & & Using A & ia Regio & onal Bilate & ral Data & & & & & & & & & Jsing As & Subregi & onal Bila & eral Dat & & & & \\
\hline & & & Panel & CA & & & & & Cross-Sec & on PCA & & & & & Panel & CA & & & & & Cross-Se & tion PC & & \\
\hline Asia & 0.187 & 0.116 & 0.156 & 0.172 & 0.186 & 0.182 & 0.174 & 0.121 & 0.154 & 0.187 & 0.179 & 0.185 & & & & & & & & & & & & \\
\hline Central Asia & & & & & & & & & & & & & & & & & & & & & & & & \\
\hline East Asia & & & & & & & & & & & & & 0.156 & 0.166 & 0.167 & 0.175 & 0.171 & 0.165 & 0.167 & 0.166 & 0.167 & 0.167 & 0.167 & 0.167 \\
\hline Southeast Asia & & & & & & & & & & & & & 0.167 & 0.170 & 0.154 & 0.175 & 0.186 & 0.148 & 0.171 & 0.130 & 0.170 & 0.185 & 0.178 & 0.166 \\
\hline South Asia & & & & & & & & & & & & & 0.139 & 0.179 & 0.155 & 0.165 & 0.181 & 0.179 & 0.145 & 0.146 & 0.158 & 0.181 & 0.202 & 0.168 \\
\hline Pacific & & & & & & & & & & & & & & & & & & & & & & & & \\
\hline Oceania & & & & & & & & & & & & & & & & & & & & & & & & \\
\hline European Union & 0.177 & 0.183 & 0.148 & 0.172 & 0.182 & 0.136 & 0.157 & 0.184 & 0.154 & 0.146 & 0.155 & 0.206 & & & & & & & & & & & & \\
\hline Latin America & 0.194 & 0.201 & 0.099 & 0.086 & 0.185 & 0.234 & 0.193 & 0.122 & 0.165 & 0.147 & 0.179 & 0.195 & & & & & & & & & & & & \\
\hline Africa & 0.148 & 0.151 & 0.239 & 0.115 & 0.176 & 0.171 & 0.209 & 0.195 & 0.075 & 0.156 & 0.237 & 0.129 & & & & & & & & & & & & \\
\hline
\end{tabular}

PCA = principal component analysis.

Source: Authors' calculations. 
Figure 13: Asia-Pacific Regional Cooperation and Integration Index, 2014, Asia SubregionsUsing Panel versus Cross-Section Principal Component Analysis-Derived Weights

(a) Panel PCA-Derived Weights
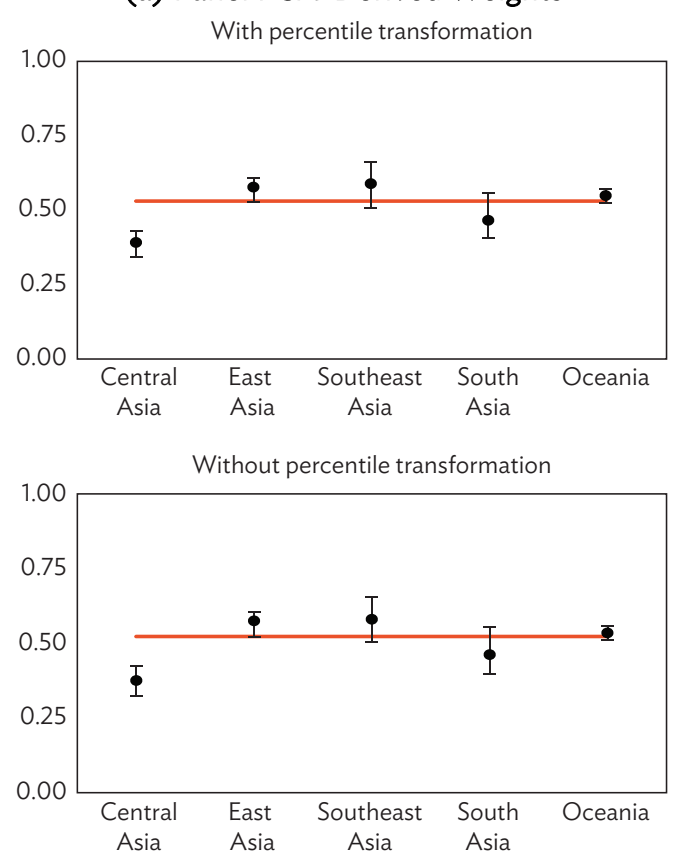

(b) Cross-Section PCA-Derived Weights
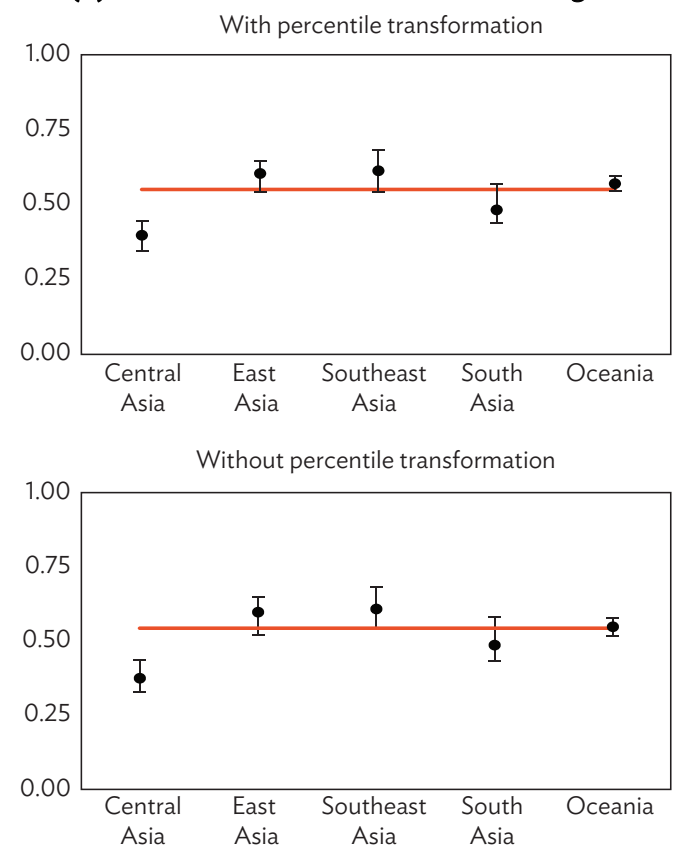

- Asian Region Average

PCA = principal component analysis.

Note: In the charts above, the maximum (upper band), minimum (lower band) and average values (thick dot) of subregional indexes as well as the average value of Asia-Pacific Regional Cooperation and Integration Index (horizontal line) are reported.

Source: Authors' calculations. 


\section{Figure 14: Dimensional Subindexes, 2014, Asia Subregions-Using Panel versus Cross-Section Principal Component Analysis-Derived Weights}

\section{(a) Panel PCA-Derived Weights}
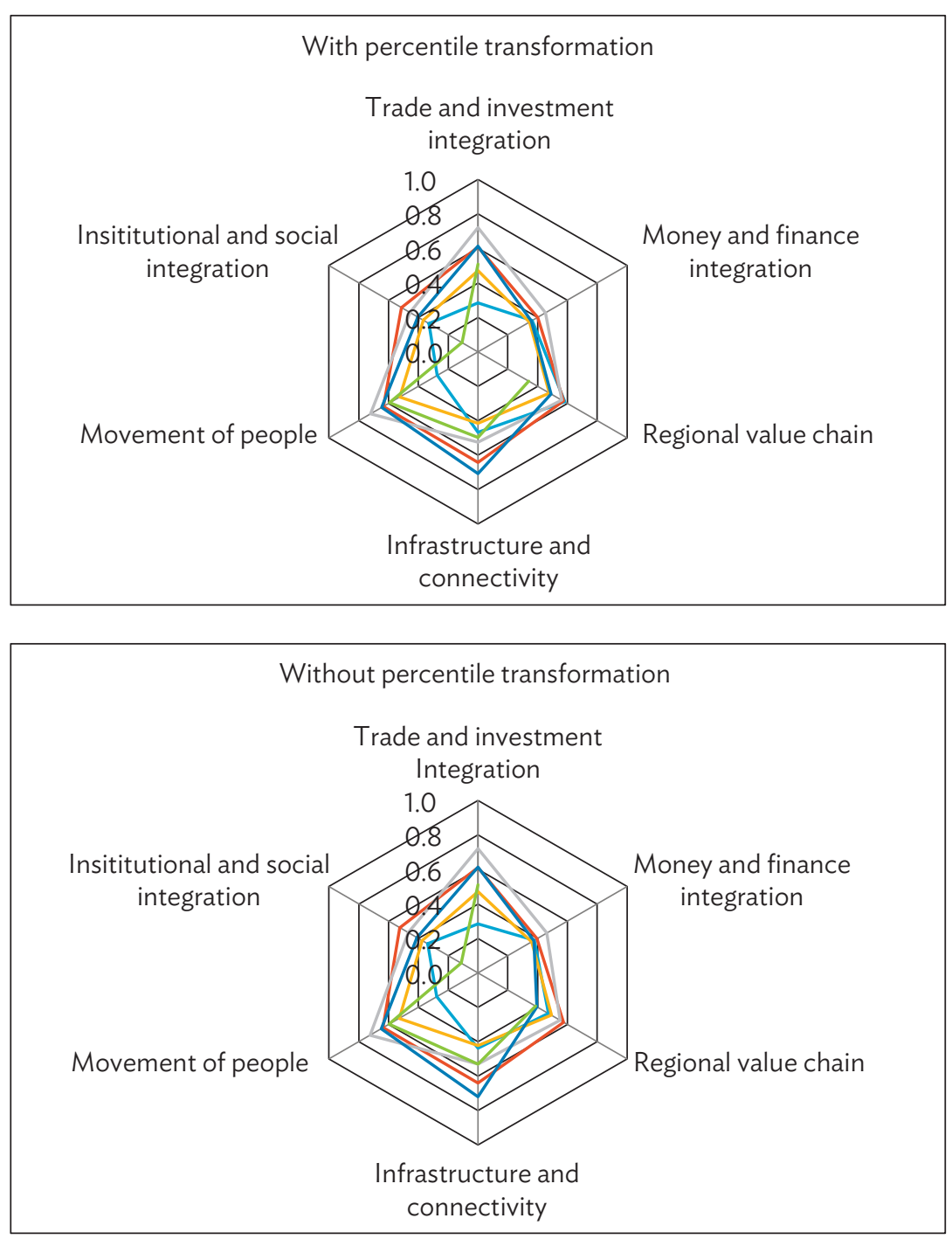
Figure 14 continued

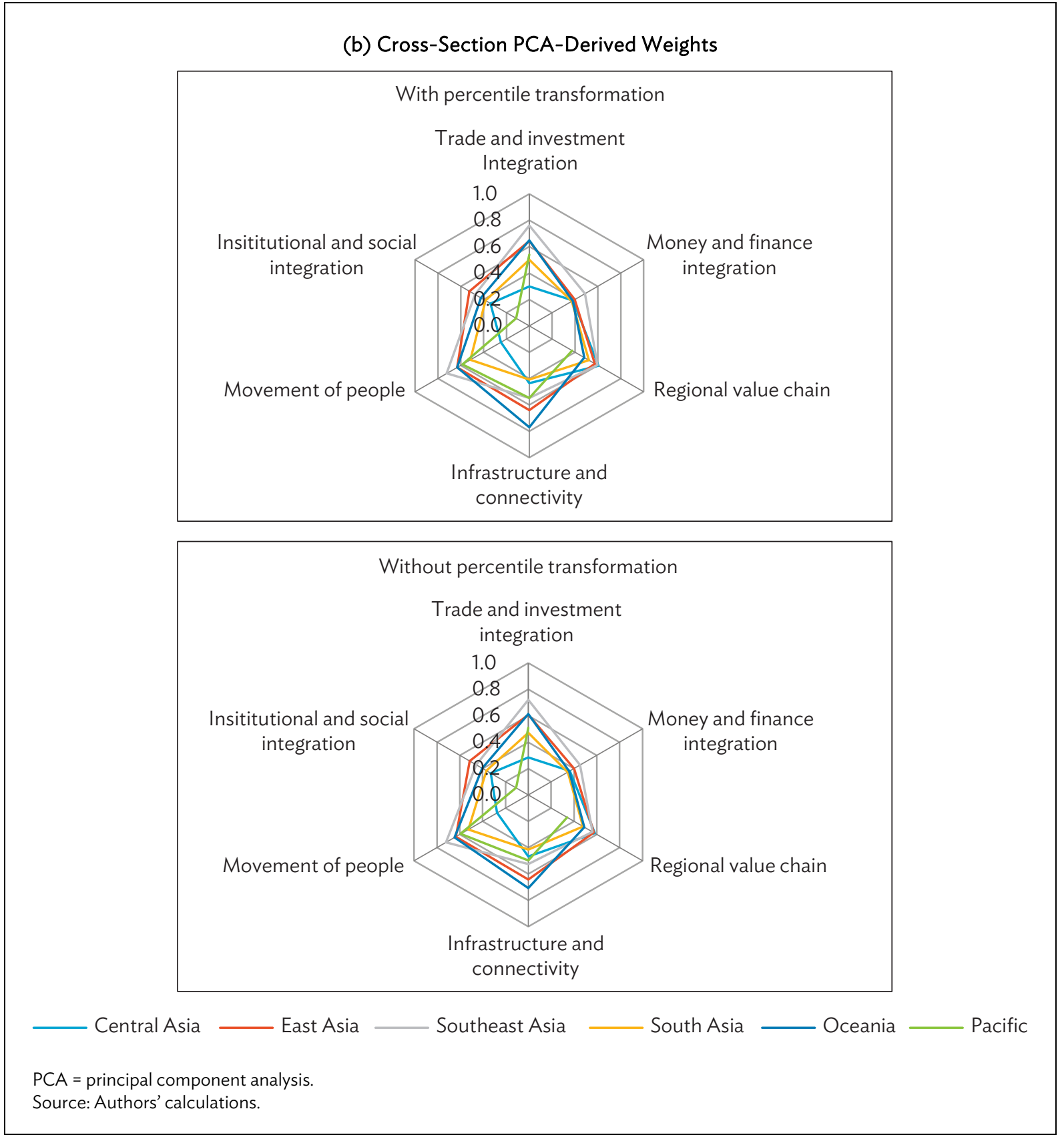


Figure 15: Regional Integration Indexes, 2014, Asia versus Other Regions-Using Panel versus Cross-Section Principal Component Analysis-Derived Weights

(a) Panel PCA-Derived Weights
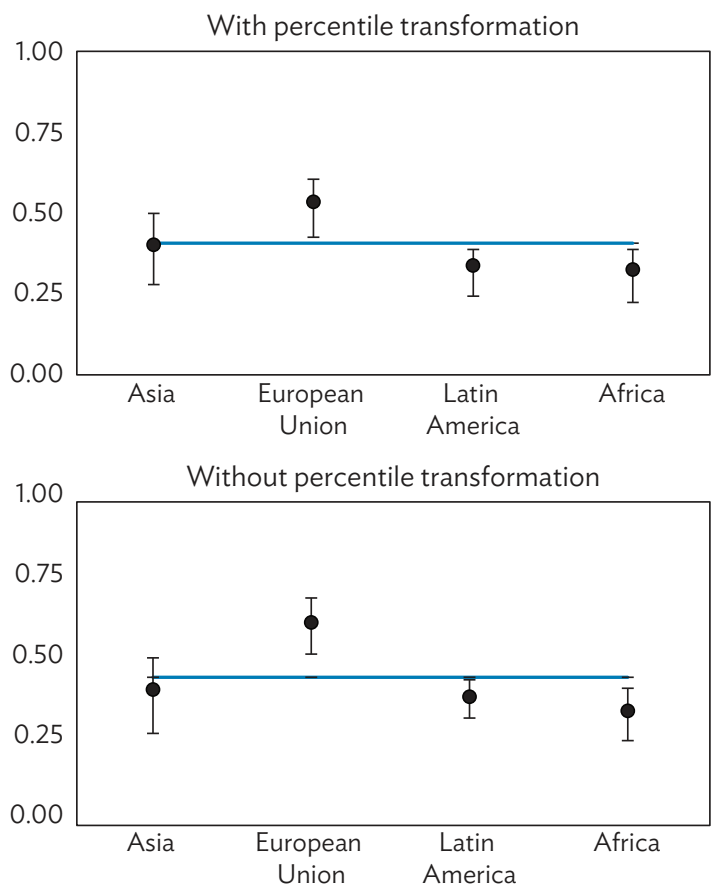

(b) Cross-Section PCA-Derived Weights
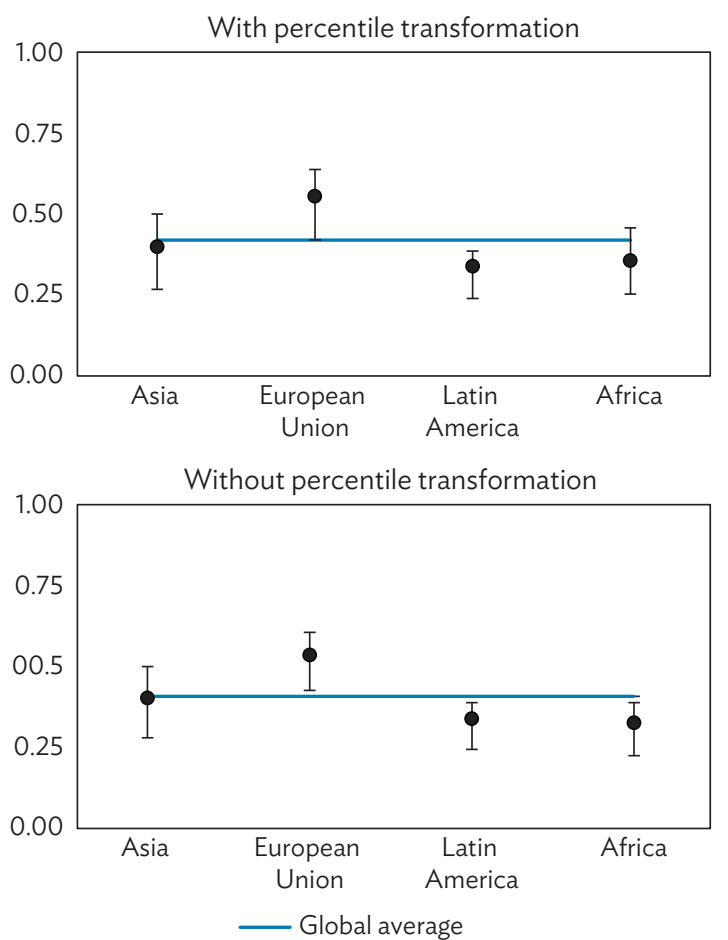

PCA = principal component analysis.

Note: In the charts above, the maximum (upper band), minimum (lower band) and average values (thick dot) of regional indexes as well as the global average value of the integration indexes (horizontal line) are reported.

Source: Authors' calculations. 
Figure 16: Dimensional Subindexes, 2014, Asia versus Other Regions-Using Panel versus Cross-Section Principal Component Analysis-Derived Weights

\section{(a) Panel PCA-Derived Weights}
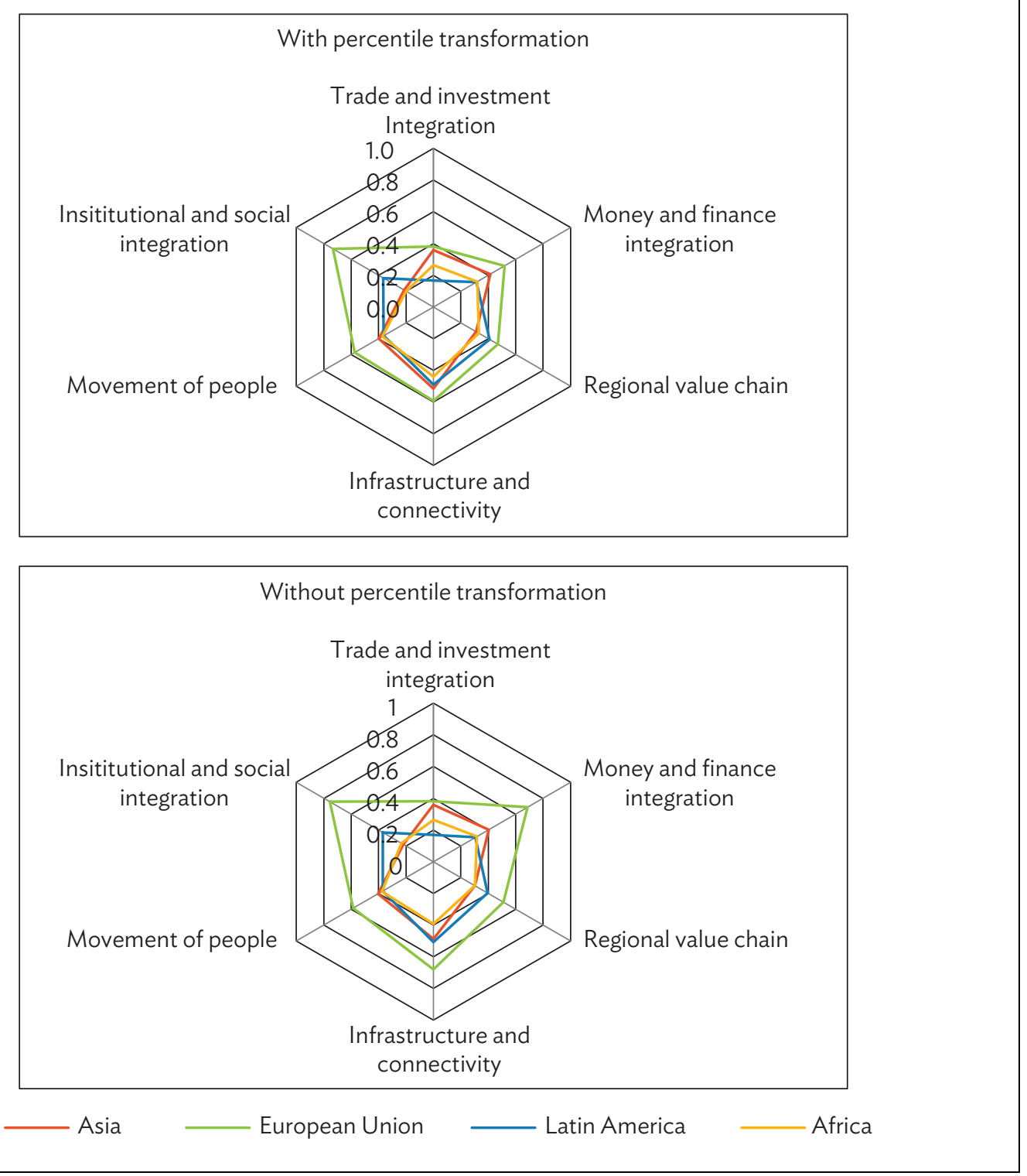

continued on next page 
Figure 16 continued

\section{(b) Cross-Section PCA-Derived Weights}
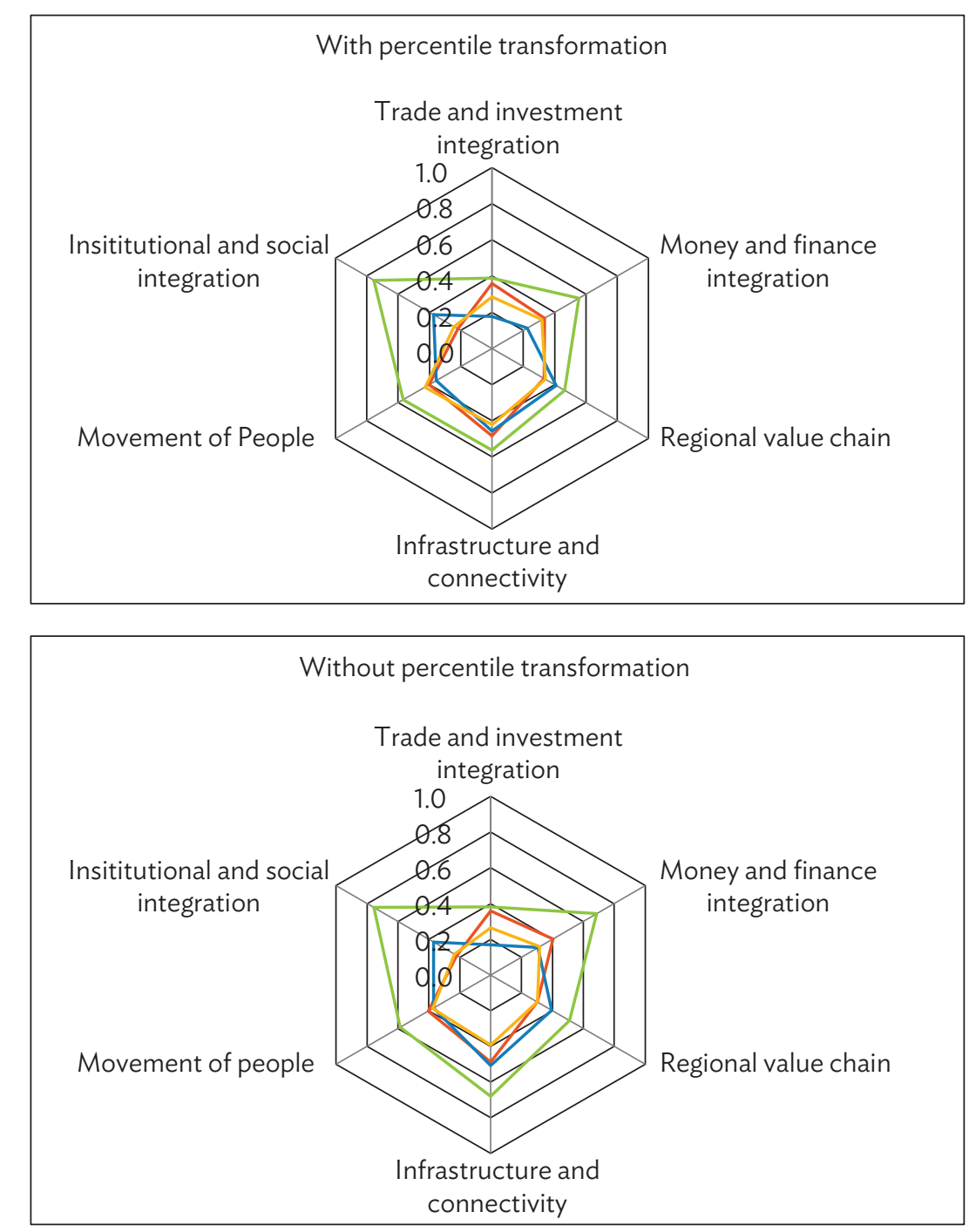

Asia European Union 


\section{CONCLUSION}

In this paper, we propose a panel approach in the construction of the ARCII, with the aim of strengthening the index's ability to track progress of regional integration in Asia and the Pacific over time. To ensure comparability across years, we made use of all available information from the entire 2006-2016 sample period. In particular, panel-based procedures are employed in imputing missing values, normalizing raw data, and deriving dimensional and subdimensional weights via PCA in compiling the ARCII.

Unlike the cross-sectional analysis employing a single year, a panel approach adds comparability of the indexes over time, which allows for a richer and more dynamic analysis of composite indexes across different periods. It enables analysis of the time evolution and identification of the main drivers and weakest links of overall integration at the subregional, regional, and global levels over different periods of time.

Although regional integration is a dynamic process, the pace of integration in Asia was broadly steady during the 11-year sample period. However, modest gains were made as most economies in the sample increased their regional integration from 2006 to 2016. Of the six dimensions of ARCII, trade and investment and movement of people appeared to be the main drivers of regional integration in terms of the size of panel PCA-derived weights, subindex magnitudes, and the significance of the dimensional contributions. The money and finance dimension was the weakest link in overall integration in Asia, based on its lowest weight and its contribution share.

On average, Southeast Asia is most integrated with Asia as a whole, while East Asia has been catching up in recent years. Central Asia is the least regionally integrated. When computed for the subregions, East Asia displays the highest level of intrasubregional integration, followed by Southeast Asia and South Asia. Meanwhile, compared to other regions, Asia comes second to the EU in regional integration, but several Asian economies-led by Malaysia and Singapore-have entered the top tier of rankings and are comparable to EU economies. Global comparison shows Asia's regional integration is driven mainly by infrastructure and connectivity and, of late, by trade and investment. The region's institutional and social integration has been consistently lower than in other regions in both magnitude and its dimensional contribution.

These results suggest there are significant policy implications for countries trying to strengthen cooperation and integration in Asia. The region has made gradual progress in regional integration, but its money and financial integration have tended to lag trade and investment and movement of people. Money and finance integration is also highly volatile and spikes during times of crisis. These features call for greater policy cooperation to ensure the region's financial stability. The findings in this paper broadly support those expressed in ADB 2017. To advance more balanced financial, social, and institutional integration across the region, collective efforts are needed to remove national barriers to regional integration, adopt regional standards, and institutionalize regional integration frameworks. 
APPENDIX: REGRESSION IMPUTATION RESULTS

\begin{tabular}{|c|c|c|c|c|c|}
\hline & $\mathrm{I}$ & II & III & IV & $\mathrm{V}$ \\
\hline Version & $\begin{array}{l}\text { Huh and Park } \\
\text { (2018) }\end{array}$ & $\begin{array}{c}\text { Park and } \\
\text { Claveria (2018) }\end{array}$ & & & \\
\hline Estimation method & OLS & Panel LS & & OLS & \\
\hline Sample & $\begin{array}{c}158 \text { economies } \\
2013\end{array}$ & $\begin{array}{c}158 \text { economies } \\
2006-016\end{array}$ & $\begin{array}{c}48 \text { Asian } \\
\text { economies } \\
2006-2016\end{array}$ & $\begin{array}{c}158 \text { economies } \\
2014\end{array}$ & $\begin{array}{c}48 \text { Asian } \\
\text { economies } \\
2014\end{array}$ \\
\hline \multicolumn{6}{|c|}{ Dependent variable: Ease of Doing Business Index (IV-d) } \\
\hline \multirow[t]{2}{*}{ Constant } & 3.82 & 7.89 & 15.93 & 3.27 & 15.27 \\
\hline & $(0.32)$ & $(0.00)$ & $(0.00)$ & $(0.39)$ & $(0.05)$ \\
\hline \multirow[t]{2}{*}{ LPI } & 19.83 & 18.17 & 16.42 & 19.65 & 16.47 \\
\hline & $(0.00)$ & $(0.00)$ & $(0.00)$ & $(0.00)$ & $(0.00)$ \\
\hline $\mathrm{R}^{2}$ & 0.64 & 0.59 & 0.59 & 0.64 & 0.55 \\
\hline Adjusted $\mathrm{R}^{2}$ & 0.64 & 0.59 & 0.59 & 0.63 & 0.540 \\
\hline \multirow[t]{2}{*}{ F-statistic } & 229.33 & 2112.01 & 573.52 & 232.42 & 43.26 \\
\hline & $(0.00)$ & $(0.00)$ & $(0.00)$ & $(0.00)$ & $(0.00)$ \\
\hline \multicolumn{6}{|l|}{ Dependent variable: LPI (IV-c) } \\
\hline \multirow[t]{2}{*}{ Constant } & 0.91 & 0.91 & 0.59 & 0.94 & 0.78 \\
\hline & $(0.00)$ & $(0.00)$ & $(0.00)$ & $(0.00)$ & $(0.02)$ \\
\hline \multirow[t]{2}{*}{ Ease of Doing Business } & 0.03 & 0.03 & 0.04 & 0.03 & 0.03 \\
\hline & $(0.00)$ & $(0.00)$ & $(0.00)$ & $(0.00)$ & $(0.00)$ \\
\hline $\mathrm{R}^{2}$ & 0.64 & 0.59 & 0.59 & 0.64 & 0.55 \\
\hline Adjusted $\mathrm{R}^{2}$ & 0.64 & 0.59 & 0.59 & 0.63 & 0.54 \\
\hline \multirow[t]{2}{*}{ F-statistic } & 229.33 & 2112.01 & 573.52 & 232.42 & 43.26 \\
\hline & $(0.00)$ & $(0.00)$ & $(0.00)$ & $(0.00)$ & $(0.00)$ \\
\hline \multicolumn{6}{|c|}{ Dependent variable: Trade cost (IV-a) } \\
\hline \multirow[t]{2}{*}{ Constant } & 2.46 & 1.79 & 0.58 & 1.61 & 0.71 \\
\hline & $(0.00)$ & $(0.00)$ & $(0.00)$ & $(0.00)$ & $(0.00)$ \\
\hline \multirow{2}{*}{$\begin{array}{l}\text { Liner shipping bilateral } \\
\text { connectivity index (IV-b) }\end{array}$} & -1.27 & -0.84 & -0.12 & -0.56 & 0.09 \\
\hline & $(0.00)$ & $(0.00)$ & $(0.00)$ & $(0.00)$ & $(0.37)$ \\
\hline \multirow[t]{2}{*}{ LPI } & -0.12 & -0.09 & -0.06 & -0.14 & -0.13 \\
\hline & $(0.00)$ & $(0.00)$ & $(0.01)$ & $(0.00)$ & $(0.06)$ \\
\hline \multirow{2}{*}{$\begin{array}{l}\text { Distance between } \\
\text { trading partners }\end{array}$} & 0.29 & 0.52 & 1.88 & 0.48 & 0.44 \\
\hline & $(0.00)$ & $(0.00)$ & $(0.00)$ & $(0.00)$ & $(0.44)$ \\
\hline $\mathrm{R}^{2}$ & 0.67 & 0.74 & 0.43 & 0.63 & 0.26 \\
\hline Adjusted $\mathrm{R}^{2}$ & 0.66 & 0.74 & 0.42 & 0.62 & 0.18 \\
\hline \multirow[t]{2}{*}{ F-statistic } & 53.94 & 986.70 & 56.49 & 66.81 & 3.15 \\
\hline & $(0.00)$ & $(0.00)$ & $(0.00)$ & $(0.00)$ & $(0.00)$ \\
\hline
\end{tabular}

$\mathrm{OLS}=$ ordinary least squares, $\mathrm{LPI}=$ Logistics Performance Index, $\mathrm{LS}=$ least squares.

Note: $p$-values in parentheses.

Source: Authors' calculations. 


\section{REFERENCES}

Asian Development Bank (ADB). 2017. Asian Economic Integration Report 2017: The Era of Financial Interconnectedness: How Can Asia Strengthen Financial Resilience? Manila. https://aric.adb.org/aeir.

Bo, Chen, and Yuen Pau Woo. 2008. A Composite Index of Economic Integration in the Asia-Pacific Region. New York: United Nations Public Administration Network. http://unpan1.un.org/intradoc/groups/public/documents/apcity/unpan049069.pdf (accessed December 2017).

Dreher, Axel. 2006. “Does Globalization Affect Growth? Evidence from a New Index of Globalization.” Applied Economics 38 (10): 1091-110.

Dreher, Axel, Noel Gaston, Pim Martens, and Lotte Van Boxem. 2010. "Measuring Globalization Opening the Black Box. A Critical Analysis of Globalization Indices." Journal of Globalization Studies 1 (1): 166-85.

Dungey, Mardi, Biplob Chowdhury, Moses Kangogo, Mohammad A. Sayeed, and Vladimir Volkov. 2017. "The Changing Network of Financial Market Linkages: The Asian Experience." Background paper for Asian Economic Integration Report 2017 Theme Chapter on "The Era of Financial Interconnectedness: How Can Asia Strengthen Financial Resilience?” Manuscript.

Gygli, Savina, Florian Haelg, and Jan-Egbert Sturm. 2018. "The KOF Globalisation Index-Revisited." KOF Working Paper 439. https://www.ethz.ch/content/dam/ethz/special-interest/dual/kofdam/documents/Globalization/2018/KOF_Globalisation\%20Index _Revisited.pdf (accessed March 2018).

Huh, Hyeon-Seung, and Cyn-Young Park. 2017. "Asia-Pacific Regional Integration Index: Construction, Interpretation, and Comparison." ADB Economics Working Papers Series No. 511. https://www.adb.org/publications/asia-pacific-regional-integration-index.

- 2018. "Asia-Pacific Regional Integration Index: Construction, Interpretation, and Comparison." Journal of Asian Economics 54: 22-38. https://doi.org/10.1016/ j.asieco.2017.12.001 (accessed February 2018).

Lockwood, Ben. 2004. "How Robust is the Kearney/Foreign Policy Globalization Index?" The World Economy 27 (4): 507-524.

Organisation for Economic Co-operation and Development (OECD). 2008. Handbook on Constructing Composite Indicators: Methodology and User Guide. European Commission. Paris.

Swiss Federal Institute of Technology Zurich. 2017. KOF Index of Globalization. http://globalization.kof.ethz.ch/media/filer_public/2017/04/19/method_2017.pdf （accessed September 2017).

United Nations Conference on Trade and Development (UNCTAD). 2007. Developing Countries in International Trade 2007. Trade and Development Index. Geneva.

World Bank. The LPI Methodology. https://wb-lpi-media.s3.amazonaws.com/ LPI\%20Methodology.pdf (accessed September 2017). 


\section{Constructing the Asia-Pacific Regional Cooperation and Integration Index: A Panel Approach}

This paper employs a panel approach in constructing the Asia-Pacific Regional Cooperation and Integration Index (ARCII) to strengthen the index's ability to track the progress of economic integration in the region over time. Of the six dimensions featured in the ARCII, trade and investment and movement of people are the main drivers of regional integration, while the money and finance dimension was the weakest link. Findings suggest the pace of integration in 2006-2016 was steady, driven by trade and investment. Modest gains in regional integration were made across most economies. Meanwhile, Asia comes second to the European Union (EU) in progress on regional integration, but in recent years several Asian economies have broken through to the top tier dominated by the EU economies.

\section{About the Asian Development Bank}

ADB's vision is an Asia and Pacific region free of poverty. Its mission is to help its developing member countries reduce poverty and improve the quality of life of their people. Despite the region's many successes, it remains home to a large share of the world's poor. $A D B$ is committed to reducing poverty through inclusive economic growth, environmentally sustainable growth, and regional integration.

Based in Manila, ADB is owned by 67 members, including 48 from the region. Its main instruments for helping its developing member countries are policy dialogue, loans, equity investments, guarantees, grants, and technical assistance.

$\mathrm{ADB}$ 